Portland State University

PDXScholar

$4-21-1998$

\title{
The Antiquities Act of 1906: The Public Response to the Use of Presidential Power in Managing Public Lands
}

Barbara L. Grover

Portland State University

Follow this and additional works at: https://pdxscholar.library.pdx.edu/open_access_etds

Part of the Geography Commons, Policy Design, Analysis, and Evaluation Commons, and the Policy History, Theory, and Methods Commons

Let us know how access to this document benefits you.

\section{Recommended Citation}

Grover, Barbara L., "The Antiquities Act of 1906: The Public Response to the Use of Presidential Power in Managing Public Lands" (1998). Dissertations and Theses. Paper 2427.

https://doi.org/10.15760/etd.2425

This Thesis is brought to you for free and open access. It has been accepted for inclusion in Dissertations and Theses by an authorized administrator of PDXScholar. Please contact us if we can make this document more accessible: pdxscholar@pdx.edu. 


\section{THESIS APPROVAL}

The abstract and thesis of Barbara L. Grover for the Master of Science in Geography were presented April 21 1998, and accepted by the thesis committee and the department.

COMMITTEE APPROVALS:

Barbara Brower, Chair

Martha Workc

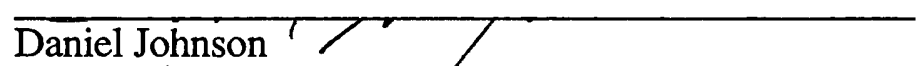

William Lang

Representative of the Qffyce of Graduate Studies

DEPARTMENT APPROVAL:

Daniel Johnson, Chair

Department of Geography 


\begin{abstract}
An Abstract of the thesis of Barbara L. Grover for the Master of Science in Geography presented April 21, 1998.
\end{abstract}

Title: The Antiquities Act of 1906: The Public Response to the Use of Presidential Power in Managing Public Lands.

President Clinton created Grand Staircase-Escalante National Monument on September 17, 1996. The Antiquities Act of 1906 gives the president power to establish national monuments on public lands through presidential proclamation. The Act has been used to create national monuments in places such as Muir Woods, Grand Canyon, Mount Olympus, Jackson Hole, and the 1978 Alaskan d-2 lands. Its use has also produced negative public response, manifested as demonstrations, lawsuits, and congressional bills.

In spite of significant legal and legislative challenges, the Antiquities Act and most of the monuments established through its use remain. The negative public response to the Act and the monuments has not been able to dissuade presidents from using executive authority. In each of the controversial cases the scope of the Antiquities Act was expanded in regards to the values being protected, monument size, or land use. The public had little influence in reversing that expansion. The 
Antiquities Act was designed as a tool to provide protection to threatened lands. It has protected federal lands, and in many cases the national interest. The historic and scientific values of once controversial monuments such as the Grand Canyon, Muir Woods Mount Olympus, Jackson Hole, and the d-2 lands, are now indisputable. These monuments have evolved to represent part of our natural national heritage. Only time will tell if the same can be said for Grand Staircase-Escalante National Monument. 


\section{' THE ANTIQUITIES ACT OF 1906? \\ THE PUBLIC RESPONSE TO THE USE OF PRESIDENTIAL POWER \\ IN MANAGING PUBLIC LANDS}

by

BARBARA L. GROVER

A thesis submitted in partial fulfillment of the requirements for the degree of

MASTER OF SCIENCE

in

GEOGRAPHY

Portland State University

1998 


\section{TABLE OF CONTENTS}

\section{PAGE}

LIST OF TABLES

iv

LIST OF FIGURES $\quad \ldots \ldots \ldots \ldots \ldots \ldots \ldots \ldots \ldots$

INTRODUCTION $\quad \ldots \ldots \ldots \ldots \ldots \ldots \ldots \ldots \ldots \ldots$

HISTORICAL BACKGROUND $\ldots \ldots \ldots \ldots \ldots \ldots$

Manifest Destiny Meets Conservation . . . . . . . . . . . . 6

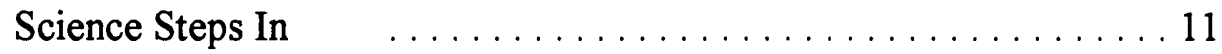

THE ANTIQUITIES ACT $\ldots \ldots \ldots \ldots \ldots \ldots \ldots \ldots \ldots \ldots$

Application of the Antiquities Act . . . . . . . . . . . 14

Interpretation of the Antiquities Act $\ldots \ldots \ldots \ldots$

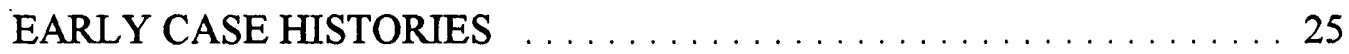

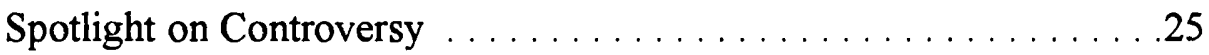

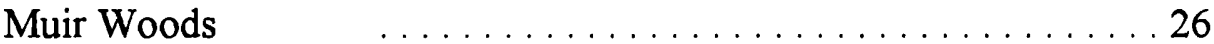

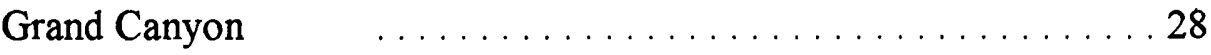

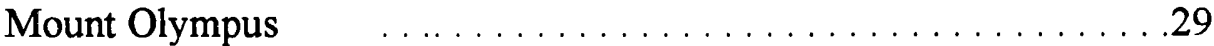

CASE HISTORY: JACKSON HOLE NATIONAL

MONUMENT $1897-1950 \ldots \ldots$. . . . . . . . . . . . . . . . . . .32

The Long Battle to Preserve Jackson Hole . . . . . . . . . . . . . . . . 32

The Public Responds . . . . . . . . . . . . . . . 41 
CASE HISTORY: PROTECTION OF ALASKA

D-2 LANDS 1971-1980 ..................... 51

Carter's Bold Move $\ldots \ldots \ldots \ldots \ldots \ldots \ldots \ldots \ldots \ldots \ldots$

Public Response to President Carter's Actions $\ldots \ldots \ldots \ldots \ldots 55$

GRAND STAIRCASE-ESCALANTE NATIONAL

MONUMENT 1995-1998 . . . . . . . . . . . . . . . . . . . . . . . 64

Preservation Efforts in Southern Utah . . . . . . . . . . . . . . . 64

The Executive Branch Takes and Interest $\ldots \ldots \ldots \ldots \ldots \ldots 67$

Promises of the President $\ldots \ldots \ldots \ldots \ldots \ldots \ldots \ldots \ldots \ldots$

The Response $\quad \ldots \ldots \ldots \ldots \ldots \ldots \ldots \ldots \ldots \ldots \ldots \ldots$

Taking Action: Protest, Lawsuits and Legistation in Response to Grand Staircase-Escalante National Monument . . . . . . . . . 76

Too Soon To Know $\ldots \ldots \ldots \ldots \ldots \ldots \ldots \ldots \ldots \ldots \ldots \ldots$

CONCLUSION $\quad \ldots \ldots \ldots \ldots \ldots \ldots \ldots \ldots \ldots \ldots \ldots$

ENDNOTES $\quad \ldots \ldots \ldots \ldots \ldots \ldots \ldots \ldots \ldots \ldots$

REFERENCES $\quad \ldots \ldots \ldots \ldots \ldots \ldots \ldots \ldots \ldots \ldots \ldots \ldots$

APPENDIX THE ANTIQUITIES ACT $\ldots \ldots \ldots \ldots \ldots \ldots \ldots \ldots$ 


\section{LIST OF TABLES}

TABLE

PAGE

I Presidential Use of the Antiquities Act, 1906-1997 . . . 17

II National Distribution of National Monuments

Past and Present, In Order of Acreage . . . . . . 18

III Current Status of National Monuments Established Through Use of the Antiquities Act . . . . . . . . 19

IV The Source Lands and Amount of Acreage Assembled

To Create Jackson Hole National Monument . . . . . 41

V National Monuments Established by Jimmy Carter

In 1978 and Their Current Status . . . . . . . . . . 65

VI Bills in Congress Related to the Grand

Staircase-Escalante National Monument and the Antiquities Act of $1906 \ldots \ldots \ldots \ldots$. . . . . 84

VII Result of Roll Call-Vote Number 495 on the National

Monument Fairness Act of 1997 in the House

Of Representatives, $105^{\text {th }}$ Congress

85 


\section{LIST OF FIGURES}

FIGURE

1. Public Land Settlement $1800-1943 \ldots \ldots \ldots \ldots \ldots \ldots \ldots . \ldots 13$

2. Map of Grand Teton National Park as Established in 1929 . . . . 39

3. Map of Jackson Hole National Monument as

Established in $1943 \ldots \ldots \ldots \ldots \ldots \ldots \ldots \ldots \ldots$

4. Map of Alaska Showing Lands Withdrawn by the President as

National Monuments, and by the Secretary of the

Interior in $1978 \ldots \ldots \ldots \ldots \ldots \ldots \ldots \ldots \ldots . .56$

5. Map of Grand Staircase-Escalante National Monument . . . . . . 65 


\section{INTRODUCTION}

The rock-dominated landscape of the Colorado Plateau covers the southeast half of Utah. Deep canyons and bizarre rock formations created by millions of years of erosion and plateau uplift display inspiring beauty. Native people have occupied the area for thousands of years, and remnants or their past are present in historical and archaeological sites. Many of these features warrant protection by the federal government. In Utah's red rock province federal authorities have established five national parks, six national monuments, and a national recreation area. The most recent addition to the collection of federally reserved land is the Grand StaircaseEscalante National Monument (Grand Staircase).

Grand Staircase was created by President Clinton in September 1996 under authority provided by the Antiquities Act of 1906 . The establishment of this 1.7 million-acre national monument generated two divergent reactions. The establishment of Grand Staircase-Escalante National Monument was a victory for environmentalists fighting to protect the red rock wilderness, but protection of Grand Staircase signaled defeat for opponents.

Protesters included anti-government groups, businessmen and women, landowners, Utah politicians, and citizens living nearby. In their view the president had interfered in the legislative process, and eliminated their right to participate in decisions affecting public lands. The new monument presented a threat to a way of 
life for those relying on public lands for their livelihood and their identity. The fears and sentiments of these people echo previous disputes between the federal government and the people of the West.

Not all people of the West have resisted and resented federal land controls. However, there exists a nebulous group of Westerners characterized by their individualism and rebellious stance towards the federal government. Though not the only citizens of the West they are the focus of this paper. To understand better who they are turn the clock back to the $19^{\text {th }}$ century, and to the mythic version of the Old West that influenced this particular identity for people in the West.

America is growing in population and in size. As the country grows, areas of unsettled land beckon settlers. This land is different from that east of the Mississippi River. It is harsher, wilder, arid, and vast. The people that settle this new land must battle the elements to survive. Their reward is a land that offers numerous resources: open range for grazing, forests for logging, and rich deposits for mining. As these resources are developed a new lifestyle, defined by the individualism and independence needed for survival, evolves. As time passes, towns grow and the western frontier closes. New economies, not reliant on the public lands of the West, develop. However, the Westerners' pride in their old public land-resource based economy and rugged heritage remains. Today the individuals who rely on that sense of identity and seek to sustain it will be defined, for purposes of this paper, as Westerners. 
Westerners have spoken out against government control of public lands since the 1890 's when the federal government began to withdraw land from the public domain. At that time an east-west dialectic developed that continues today. In part, that conflict arises from resentment to being subjected to decisions made in the East. The extent of eastern control has been strong enough for the West to be considered "in a sense a colony" (Goetzman 1981, 117). The East-West debate has evolved to include many factional dialectics. These include, but are not limited to urban vs. rural, government vs. citizen, group vs. individual, outsider vs. local, and long-term vs. short-term goals.

The establishment of Grand Staircase encompasses all of these factors. President Clinton is an "easterner" with urban roots representing the federal government and making decisions in a location distanced from the land he controls. The locals question and resent his authority. In response, lawsuits and congressional bills have been drafted. The lawsuits and bills seek reversal of the president's proclamation, and limitations to future proclamations.

The lawsuits may be in vain. Clinton has the authority to control public lands. The United States Constitution gives the president executive privilege, which can be applied to public land management. The Antiquities Act of 1906 (the Act) gives the president the power to establish national monuments on public lands through presidential proclamation. From its inception, only one president has NOT used the Act: over 140 national monuments have been created. The current lawsuits and legislation may determine how future presidents use the Act to protect public lands. 
This paper describes the Antiquities Act, its history, its ambiguous nature, the limits of its authority, and the public's response to its use. The focus is on several case histories that highlight the public's response. To understand why Westerners have responded as they have requires some background on ideology and history. A brief history of the events preceding the passing of the Antiquities Act is followed by a description of the development of western attitudes. Finally, a summary of the establishment of the more controversial national monuments follows. This provides a framework to the current controversy over Grand Staircase-Escalante National Monument.

Although encompassing elements of regional history, sociology, and public policy, the elements of place, pattern, and change make this story inherently geographic. Geography studies the shape of the land and factors that affect change, including interactions between culture and the landscape. In part, the landscape is an expression of the cultural responses of the people living there: politics, perception, and values determine land use, boundaries, and sentimental attachment to a place. Donald Meinig implied this when he wrote, "any landscape is composed not only of what lies before our eyes but what lies within our heads" (quoted in Wright 1993, 43). Often, as in the case of the West, "what lies within our heads" is a mythical interpretation of landscape's legacy. The response of Westerners to changes in federal land designations, and the struggle between development, an old way of life, and conservation is grounded in geographic interpretation. 
Other geographers have blended the historical and cultural foundations of the discipline to explain regional attitudes towards land use, and preservation. For example, conservation of private lands in the Rocky Mountains was studied by John Wright who wrote, "the western landscape is the most splendid and meaningful cultural artifact...The controversy over the conservation of ecological, recreational, and historical resources in the Rocky Mountain West is basically a conflict between those who see the region as vacuous space and those who experience it as a bountiful web of places" ( Wright 1993, 43). Clearly, even within a cultural group perceptions and opinions vary, illustrating the depth and complexity of a culture's influence on the landscape.

Making sense of a place and its multi-faceted people is the quintessential geographic task. The goal of this paper is to provide a geographic perspective to the body of literature chronicling the West, by describing and comparing responses to land use and land management issues, such as those raised by the implementation of the Antiquities Act. Understanding the people of the West and their response to the actions of the federal government, especially the President of the United States, is elemental to understanding the West as a whole. 


\section{HISTORICAL BACKGROUND}

\section{MANIFEST DESTINY MEETS CONSERVATION}

The paradigm of public land disposal in the United States originated in colonial times. Thomas Jefferson and other influential leaders of the time advocated an agrarian society, and encouraged settlers to search out locations to farm and eventually own. After independence from Great Britain the expanding population of the colonies drove land-seeking pioneers westward. Several settlement acts in the 1800 's further promoted growth on the frontier. The expansion of the United States became manifest destiny.

The same year the first wagon trains headed west to California, congress passed the General Pre-emption Act of 1841. This act and others like it promised land, at a modest price, to those willing to work for it. From 1841 to the beginning of the $20^{\text {th }}$ century the passage of each new settlement act resulted in a surge of pioneers and land claims. (See Figure 1.) Western settlement served many purposes: "lands were transferred to private ownership to encourage settlement, to stimulate railroad and wagon road construction, as rewards for military service, to aid education, to provide revenue, and for other purposes" (Foss 1987, xiv). By 1904 over 718,819 entries totaling 96,495,030 acres had been filed using the Preemption, Homestead, Desert Land, and Timber Culture Acts (Gates 1968). 
As the West was being settled resources in other parts of the country were becoming depleted. Americans in the north and east became increasingly concerned about declining timber reserves and conservation awareness began to grow. The perception that the quality and the quantity of timber were diminishing created the concern of dependence on low-grade logs or on imported timber. Denudation and overgrazing of the forestlands also presented a threat to watersheds. The public also became increasingly aware of problems resulting from the federal land disposal acts. Speculators and greedy cattle barons unlawfully appropriated tracts of land (Gates 1968).

Before the end of the $19^{\text {th }}$ century many thoughtful people became aware of the value and future significance of the natural resources still held by the Federal government and of the need for giving more attention to the methods of managing and disposing of them (Gates 1968, 771).

Congress took action to curtail land law abuses by passing the General Revision Act of 1891 repealing or revising homestead and preemption laws. The General Revision Act also included a rider that allowed the president to create forest reserves, so it is often referred to as the Forest Reserve Act of 1891. Less than a month after the Forest Reserve Act became law President Harrison withdrew over 1.2 million acres of forestland near Yellowstone National Park. Harrison also withdrew the Grand Canyon from homestead status by proclaiming it a forest reserve using the Forest Reserve Act. Before the end of his term in 1892 Harrison created over thirteen million acres of forest reserve. In 1893 President Cleveland proclaimed 4.5 million acres of forest reserves and by 1897 had created 13 other reserves (Petulla 1988). 
The federal control over forest lands was viewed as meddlesome in the West. ${ }^{1}$ "The West voiced little opposition to the first series of President Harrison's forest reservations" but with President Cleveland's 1897 reserves "the struggle between the Executive Branch and the West reached a new intensity" (Petulla 1988, 303). The backlash from the West was based on several factors. Prior to the Forest Reserve Act and the creation of the Division of Forestry in 1875 , individual states were responsible for regulating forest practices. To Westerners, federal control over forestlands indicated a loss of political power and a violation of state's rights.

Westerners also held the belief that they were not getting the same opportunities as Eastern settlers. They felt that "if early settlers of the eastern states had enjoyed the right to dispose of lands in their own way, the West should be entitled to the same privilege" (Pettulla 1988, 304). This concern echoed early disputes with the federal government over public land. Public land states were "admitted into the Union 'on equal footing with the original states, in all respects, whatever,' yet were denied ownership of the ungranted land within their own boundaries" (Gates 1968, 766).

Even in the $19^{\text {th }}$ century western lifestyle and attitudes were well developed. The land itself has been instrumental in influencing these attitudes. When the West was still unsettled the vast open spaces were overwhelming (Limerick 1987) and required a different management strategy from the public lands of the east. The government's policy of land disposal seemed hardly able to cope with taming the land. Land disposal acts were modified to address the vastness and physical differences of 
the terrain. The original Homestead Act granted allotments of 160 acres, which proved insufficient to support farmers and ranchers of the arid west. The need for larger tracts of land was recognized by congress through acts such as the Desert Land Act of 1877, Enlarged Homestead Act of 1909 and the Stock-Raising Act of 1916 (Athearn 1986). These acts allotted tracts of 320 to 640 acres.

The result was twofold. First, the federal government's eagerness to give away land provided the public with the impression of infinite resources. Even the acts that restricted land disposal did so only to reduce the influence of speculators and unauthorized uses. Second, an appropriative view of land ownership developed. The homesteading laws only required that the land was improved and occupied by the settler. This appropriative view when applied to Western water rights eventually became the foundation for Western water law.

With the eventual "closing" of the frontier westerners and the federal government came to realize the finiteness of the land and its resources. The federal reserves of land removed from the public domain grew, but use of federal land by the public continued. Government agencies issued grazing, logging, and mining permits to those wanting to extract resources from the public lands.

Today, the federal government owns large tracts of land in many western states: an estimated 50 percent of the lands of the West. Many ranchers, loggers, and miners rely on federal land access for their livelihood. The appropriative tenet of if you use it, produce income from it, and tame it, it is yours, is applied by Westerners to leased government land in spite of lacking legal support for their position. 
Another factor influencing the possessiveness of Westerners to government land is based on basic human behavior. Many of the conflicts arise because of disagreements over whose territory it is. ${ }^{2}$ The government's policy allowing resource extraction on federal lands has, in many cases, evolved into territorial attachment by their tenants. When the government "suddenly" tries to exert its ownership rights by changing the designation of the land, as in the case of a national monument proclamation, conflict arises. The Westerner conditioned with an appropriative, territorial view of public lands perceives a threat to his territory and way of life.

Territoriality and possessiveness of resources created a stance characterized by Westerners' reluctance "to share their source of wealth with the established East" (Rothman 1989,16). They saw the federal interference as a way to limit their ability to make a living. The government in the east controlled grazing, mining, and timber cutting on western lands. Westerners felt the ability to manage the land and determine their own destiny was compromised (Graf 1990). To compound the issue of selfdetermination, many federal bureaucrats had never been to the West. Rather than rely on first-hand knowledge their decisions were based on scientific information. This brought criticism from Westerners not willing to trust science. Book knowledge was not accepted as a substitute for experience on the land (Rothman 1989). 


\section{SCIENCE STEPS IN}

The increasing catalogue of knowledge on the West was one of the catalysts driving the conservation movement. Near the turn of the century scientific disciplines like geology and archaeology were expanding, becoming more established and credible (Rothman 1989). The West was an open book waiting to be explored and documented by these new scientists. As researchers headed west and became more organized, the scientific wealth of the region made it a hotbed of discovery. Sites significant for paleontology and archaeology research were discovered with increasing frequency.

These sites had fossils and artifacts of value. Two types of individuals vied for control of these artifacts: researchers and profiteers. The scientists wanting to document the sites for future study and save the artifacts for research were racing against the pottery and fossil hunters who sold the their treasures for profit. Areas significant because of their research value needed to be protected and preserved. Many important scientific sites were pillaged or vandalized before research could be done. The scientific community started to become outraged and fought back.

The battle to protect sites of scientific and historic interest, though taking place for many years all over the West, finally reached congress in 1900. In that year John Dolliver, a Representative from Iowa, introduced a bill that would authorize the president to create archaeological, scientific, and historic reservations. The east-west dialectic reared up notifying both sides of a battle. Western politicians countered with a bill to address vandalism of prehistoric ruins. The debate over the two bills 
eventually resulted in both being set aside. The fight to protect sites continued, but until 1905 all attempts at legislation failed.

In 1905, Edgar J. Hewitt, an archaeologist, drafted a bill and acquired sponsors to present his bill in the House of Representatives and the Senate. The bill passed with little debate. Westerners were originally suspicious of Hewitt's bill because of the exuberant use of presidential power following the Forest Reserve Act of 1891. Their uneasiness, however, was placated by reassurance that the bill was designed to protect "old objects of special interest" (Rothman 1989, 47). Their lack of concern is attributed to the small size of most archaeological sites. The reservation and protection of a few small sites did not present a threat to the western way of life.

Hewitt's bill was signed into law by Theodore Roosevelt and became the Antiquities Act of 1906. (See Appendix.) 


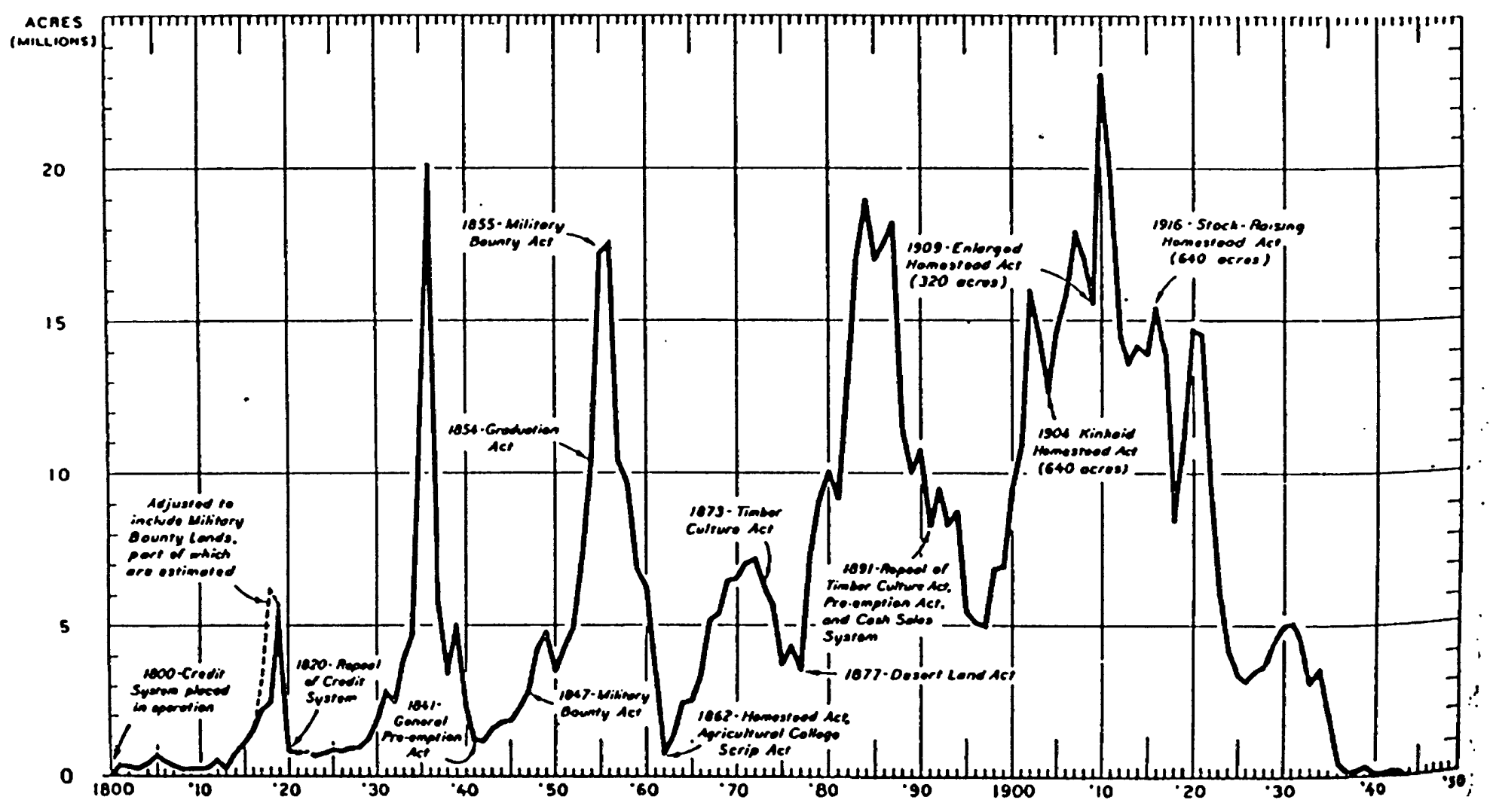

Figure 1. Public Land Settlement 1800-1943. Graph showing the number of acres claimed as influenced by public land policies. (Source: Petulla 1988, 306.) 


\section{THE ANTIQUITIES ACT}

\section{APPLICATION OF THE ANTIQUITIES ACT}

Since the inception of the Antiquities Act of 1906 seventeen Presidents have been in office: Theodore Roosevelt, William Taft, Woodrow Wilson, Warren Harding, Calvin Coolidge, Herbert Hoover, Franklin Roosevelt, Harry Truman, Dwight D. Eisenhower, John F. Kennedy, Johnson, Richard M. Nixon, Gerald Ford, Jimmy Carter, Ronald Reagan, George Bush, and Bill Clinton. Only one, George Bush, failed to use the Antiquities Act to withdraw lands from the public domain. The other sixteen signed 141 proclamations establishing, or reestablishing, national monuments totaling over sixty-nine million acres.

Not all presidents have issued proclamations with equal zeal. (See Table I.) In three years Teddy Roosevelt reserved over 1.6 million acres, creating eighteen monuments. During his terms in office Franklin Roosevelt established twenty-three monuments of over 1.5 million acres. Jimmy Carter set aside nearly 56 million acres of Alaska land as national monuments on one day. Carter's overwhelming environmental gesture will be discussed in detail in a later chapter. Bill Clinton has created a single 1.7 million-acre monument. In contrast, Ronald Reagan, in office for eight years, re-established one national monument of 184 acres. During their terms in office Gerald Ford created one, John F. Kennedy established two; and Richard M. Nixon proclaimed four national monuments. 
TABLE I

PRESIDENTIAL USE OF THE ANTIQUITIES ACT, 1906-1997

\begin{tabular}{llcr}
\hline President & Term & \# of NMs & Total Acreage \\
\hline Teddy Roosevelt & $1906-1909$ & 18 & $1,609,115$ \\
William Taft & $1909-1913$ & 12 & 40,352 \\
Woodrow Wilson & $1913-1921$ & 11 & $2,946,094$ \\
Warren Harding & $1921-1923$ & 10 & 10,231 \\
Calvin Coolidge & $1923-1929$ & 12 & $2,452,917$ \\
Herbert Hoover & $1929-1933$ & 12 & $2,697,418$ \\
Franklin Roosevelt & $1933-1945$ & 23 & $1,585,508$ \\
Harry Truman & $1945-1953$ & 7 & 2,362 \\
Dwight Eisenhower & $1953-1961$ & 5 & 6,921 \\
John Kennedy & $1961-1963$ & 2 & 1,190 \\
Lyndon Johnson & $1963-1969$ & 5 & 139,736 \\
Richard Nixon & $1969-1974$ & 4 & 29,204 \\
Gerald Ford & $1974-1977$ & 1 & 15,200 \\
Jimmy Carter & $1977-1981$ & 17 & $55,965,000$ \\
Ronald Reagan & $1981-1989$ & 1 & 184 \\
George Bush & $1989-1993$ & 0 & $\mathrm{NA}$ \\
Bill Clinton & $1993-?$ & 1 & $1,700,000$ \\
\hline Total & & 141 & $69,201,432$ \\
\hline
\end{tabular}


The presidents in office between Teddy Roosevelt and Franklin D. Roosevelt. issued comparable numbers of proclamations: Taft issued twelve, Wilson eleven, Harding ten (although in only two years), Coolidge twelve, and Hoover twelve. After Franklin Roosevelt's term only Carter issued more than seven proclamations. The change in frequency of use can be attributed to several aspects of the political climate: the increased influence of Congress in the management of public lands, the backlash response to previous use of presidential power, and the presidential commitment to conservation (Rothman 1989).

The distribution of the national monuments across the country is as uneven as the use of the Antiquities Act over time. Only thirty-two states, the District of Columbia, and the Virgin Islands have national monuments. Of those states east of the $100^{\text {th }}$ meridian twenty-two have national monuments. Those forty-five national monuments comprise less than one percent $(462,062$ acres) of the total acreage $\left(69,201,432\right.$ acres) of all monuments. All twelve states west of the $100^{\text {th }}$ meridian (excluding Hawaii) have had at least one national monument comprising over $68,739,370$ acres. (See Table II.)

Designation does not guarantee permanency: the status of some national monuments has changed. A president's executive order creating a national monument can be reversed by another president, or by an act of congress. Monuments can be abolished, converted to other designations, or "upgraded" to national park status. Only ten monuments $(16,074$ acres $)$ have been abolished. Some of those still exist as parks, but they are no longer managed by the federal government. Fifty-seven sites 
TABLE II

NATIONAL DISTRIBUTION OF NATIONAL MONUMENTS, PAST AND PRESENT, IN ORDER OF ACREAGE

\begin{tabular}{l|cr}
\hline State & \# of NMs & Acres \\
\hline New Jersey & 1 & 2 \\
Maryland & 1 & 43 \\
Mississippi & 1 & 49 \\
Tennessee & 2 & 67 \\
Ohio & 2 & 71 \\
Texas & 1 & 93 \\
Missouri & 1 & 210 \\
North Dakota & 1 & 253 \\
Alabama & 1 & 310 \\
Nevada & 1 & 593 \\
New York & 5 & 715 \\
Virgin Islands & 1 & 880 \\
Montana & 3 & 930 \\
Minnesota & 2 & 992 \\
lowa & 1 & 1,481 \\
West Virginia & 1 & 2,239 \\
Maine & 2 & 5,035 \\
Dist. Of Columbia & 1 & 5,264
\end{tabular}

\begin{tabular}{l|c|r}
\hline State & \# of NMs & \multicolumn{2}{|c}{ Acres } \\
\hline Nebraska & 3 & 6,202 \\
Georgia & 3 & 6,263 \\
Virginia & 4 & 11,083 \\
Oregon & 2 & 14,871 \\
South Carolina & 3 & 15,268 \\
Idaho & 1 & 53,545 \\
Florida & 5 & 160,645 \\
New Mexico & 11 & 211,301 \\
Wyoming & 5 & 231,559 \\
South Dakota & 3 & 244,897 \\
Colorado & 9 & 288,832 \\
Washington & 3 & 639,262 \\
Arizona & 20 & $1,731,842$ \\
Utah & 10 & $1,811,513$ \\
California & 10 & $2,792,917$ \\
Alaska & 21 & $60,962,205$ \\
\hline TOTALS & 141 & $69,201,432$ \\
\hline
\end{tabular}


remain under federal control but have been converted to other designations such as: National Park, National Battlefield, National Memorial, National Historic Trail, National Historic Park, and National Preserve. (See Table III.)

\section{INTERPRETATION OF THE ANTIQUITIES ACT}

Controversy has always surrounded the Antiquities Act of 1906 (the Act). Historian Robert Righter states, "confusion has reigned in regard to the meaning and function of national monuments" (Righter 1982, 104). The confusion is a result, in part, of the ambiguity of the Antiquities Act. Other laws that authorize the use of presidential privilege have been similarly vague. As a result the use of presidential power can generate strong conflicting opinions regardless of what is being mandated.

The President of the United States was granted executive privilege long before the need for the Antiquities Act was even acknowledged. Constitutional authors debated the role of the president, but failed to incorporate their interpretation of the appropriate extent of presidential power into the Constitution (Berger 1974). The sole, specific reference to presidential power in Article II, Section 1 of the Constitution states:

The executive power shall be vested in a President of the United States.

That brief statement is full of ambiguity. Article II raises the question, "is this an introductory statement, or is it a grant of inherent power to protect the national 
TABLE III

CURRENT STATUS OF NATIONAL MONUMENTS ESTABLISHED THROUGH USE OF THE ANTIQUITIES ACT

\begin{tabular}{lcr}
\hline \multicolumn{1}{c}{ Current Status } & \# of Sites & Acreage \\
\hline Abolished & 10 & 16,074 \\
International Historic Site & 1 & 35 \\
National Battlefield & 1 & 5 \\
National Historic Park & 6 & 41,612 \\
National Historic Site & 8 & 5,904 \\
National Historic Trail & 1 & 160 \\
National Monument & 74 & $7,365,269$ \\
National Memorial & 1 & 14 \\
National Park & 32 & $39,862,260$ \\
National Preserve & 3 & $10,110,000$ \\
National Reserve & 1 & $10,600,000$ \\
National Wildlife Refuge & 1 & $1,200,000$ \\
National Scenic Trail & 2 & 99 \\
\hline
\end{tabular}


interest?" (Hirschfield 1968, 2). Limits as to where or how executive power can be used are not specified in Article II. Other sections of the Constitution make references to the extent of the president's authority, but provide no absolute answers (Corwin 1984). The debate over what the drafters of the Constitution intended is complex and lengthy. Generally, the use of executive order is primarily reserved for foreign relations and wartime actions. In regards to public lands most presidents have not used executive privilege, except where specifically authorized by congress.

Congressional approval of the Forest Reserve Act of 1891 provides specifically for the use of executive authority by allowing the president to withdraw lands from the public domain. Presidents William Harrison, Grover Cleveland, and Teddy Roosevelt used the act extensively to protect forestlands. They were able to reserve lands, but had to rely on Congress to appropriate funds for the protection of the timber from fire or theft (Petulla 1988). Consequently, the power of the president to protect the national interest, using this legislation, was limited by the willingness of congress to cooperate.

With the Antiquities Act of 1906 more power was vested in the president. As in the use of power authorized by Article II and the Forest Reserve Act, the use of the Antiquities Act fosters conflict. Some of the objections to the implementation of the Antiquities Act arise from the departure the explicit intention of the law. The individuals who drafted the bill and passed the law intended to preserve small sites of historic or archaeological interest. John F. Lacey, the bill's sponsor, considered one objective of the Antiquities Act to be "to preserve ... old objects of special interest" 
(quoted in Rothman 1989, 47). These were sites considered unsuitable for the privilege of national park status, but needing preservation (Rothman 1989).

Despite the intentions of the drafters, the Act has been used many times to protect lands without obvious historical or archaeological value. The Act provides for protection of scientific objects, but by 1909 'there were almost as many 'scientific' reasons for the establishment of a monument $\mathrm{s}$ there were national monuments. The Antiquities Act placed few limitations upon potential national monuments... In different situations, the Antiquities Act could be, and was, interpreted loosely" (Rothman 1989, 71).

Theodore Roosevelt is responsible for setting many precedents in the use of the Act. He viewed himself as a steward: the protector and representative of the common man's will. He believed that unless the Constitution specifically forbids it, it was his duty as president to take action (Hirshfield 1968). With authorization from congress, as in the case of the Antiquities Act, Roosevelt had few reservations about exercising his executive privilege.

The first few monuments established drew little attention to the new act. However, by 1908 the public was becoming aware of the new presidential powers authorized by congress. Two controversial monuments, Muir Woods and Grand Canyon, served to propel the president's use of the act into the public eye (Rothman 1989). Developers threatened both areas. Roosevelt intervened, using the Act as an emergency measure to prevent irreparable damage to the areas' values. The public responded by questioning the legality of the president's actions ${ }^{3}$. However, the Act 
grants such legal authority to the president by specifically authorizing the use of executive privilege to reserve public lands.

The Antiquities Act is similar to Article II in two ways. First, it was designed to protect national interests. In the case of the Antiquities Act the national interests protected are public lands and their important historic, archaeological, and scientific values. Second, the limits to the president's power are open to interpretation. This is due, in part, to the ambiguous nature of the Act. The following are phrases from the Antiquities Act that have been cause for debate.

1. "The President is authorized, in his discretion..."

The authority vested by this phrase has been interpreted as executive power. This means that the President is authorized to use his own judgment when making a proclamation. The act does not specifically require public, congressional, or cabinet input or approval. The removal of the public from the process and the autonomous action of the President have been challenged several times in the history of the Act, including the response to Grand Staircase.

2. “... historic landmarks, historic and prehistoric structures, and other objects of historic or scientific interest..."

Each item listed in this phrase needs further definition. How are landmarks and structures defined? What is an object of historic or scientific interest? The definition of these phrases seems to have expanded to suit the president issuing the proclamation. One of the objectives in the establishment of Muir Woods National Monument was the preservation of the scientific value of the land. The argument has 
been made that an area of scientific value differs from an object of scientific interest. This was one of the issues raised in disputes over the establishment of Muir Woods National Monument and Jackson Hole National Monument.

3. "And may reserve... parcels of land..."

The reservations referred to in the Act are carved from lands withdrawn from the public domain. In some situations private and state inholdings have been incorporated into national monuments; this was the case with Jackson Hole and Grand Staircase. Federal lands within the monument may be subject to management changes, raising fears that cattle may no longer be allowed to graze under the same permits, mining claims may be forfeited, and logging operations may be halted. In most circumstances homesteading is not permitted. The Act has been used to restrict exploitation of public land resources. Mining and uncontrolled tourist developments were threatening the Grand Canyon when Teddy Roosevelt proclaimed it a National Monument in 1908. In addition, restrictions on the federal lands may restrict development activities on inholdings or adjacent parcels. This was the case for Grand Staircase and lands President Jimmy Carter protected in Alaska.

4. “...confined to the smallest area compatible with the proper care and management of the objects to be protected."

"Smallest area compatible" only vaguely defines the limits for determining the appropriate size of a national monument. The smallest national monument ever created was only one half acre and the largest are millions of acres. The 56 million acres withdrawn in Alaska by Jimmy Carter in 1978 surely tested the definition of 
small. Grand Staircase has also been criticized for its large size. Proponents claim that 1.7 million acres exceeds the "smallest area compatible" requirement of the Act. Even the 1908 withdrawal of the Grand Canyon was contested as large beyond the scope of the Antiquities Act's authority.

5. "No further extension or establishment of national monuments in Wyoming may be undertaken except by the express authority of Congress."

This section limits the executive power of the president. The battle over the creation of Jackson Hole National Monument was the catalyst. The events that lead to this amendment of the Antiquities Act are indicative of the strong reaction from local citizens and politicians to the use of presidential power. This is a rare case where the response of the public was effective in reducing the authority of the President. In response to the establishment of Grand Staircase, bills that would add similar amendments were presented in the $104^{\text {th }}$ and $105^{\text {th }}$ Congress. Congressmen from Idaho, California, Washington, and Utah sponsored those bills, which will be discussed in a later chapter. 


\section{EARLY CASE HISTORIES \\ SPOTLIGHT ON CONTROVERSY}

Public land policy changes mandated by the application of the Antiquities Act have resulted in controversy, particularly in the West. In the battle over control of public lands, the government, preservation advocates, and Westerners often disagree about which lands are appropriate for withdrawal from the public domain. This paper focuses on some of the controversy arising from the use of the Antiquities Act. Though each case discussed here has kindled positive and negative responses, opposition is the focus of this study. Citizens opposed to the application of the Antiquities Act have spoken out against new monuments, acted out in civil disobedience, and instigated lawsuits and legislation. The case histories that follow, however, show that the response of the opposition has been insignificant in making major changes in the use of the Antiquities Act.

Not all national monuments create controversy. Many of the early monuments inspired little to no response from the public. The first four monuments were carved from lands that the General Land Office (GLO) had already withdrawn from the public domain. The temporary GLO withdrawals were applied to lands considered to be lacking in agricultural value but with potential for other uses (Rothman 1989). These monuments, Devil's Tower, El Morro, Montezuma's Castle, and Petrified Forest, were considered remote and inaccessible wastelands. The other monuments established in 1906 and 1907 were similar in character. 


\section{MUIR WOODS}

Muir Woods, however, was neither remote nor wasteland. Located only 12 miles north of San Francisco, Muir Woods had tremendous resource potential in its groves of coast redwood trees (Sequoia sempervirens). William Kent, a local conservationist, saw the ecological value of the woods. In 1905 he purchased 297 acres of land for $\$ 45,000$. The woods also had economic value. The timber would have been useful for rebuilding San Francisco after the 1906 earthquake. The land had value for water storage. A 1906 water development scheme designed by James Newlands of the North Coast Water Company aspired to create a reservoir to provide San Franciscans with water. Newlands' plans would require Kent's cooperation since the proposed reservoir would flood 47 acres of Kent's redwood forest (Rothman 1989).

Kent, determined to protect one of the last stands of redwoods in the San Francisco Bay Area, decided not to sell to Newlands. Newands, determined to see his dream of a reservoir become reality, filed a condemnation suit on the 47 acres. Kent was aware that the public was more interested in water than trees. On December 26, 1907, before he could be served with court documents, Kent sent the deed to his 297 acres to the Secretary of the Interior requesting that the government accept his donation and proclaim the lands a national monument. Teddy Roosevelt responded immediately by signing the proclamation creating Muir Woods National Monument on January 8, 1908 (Rothman 1989). National monument status was not enough to discourage Newlands from further pursuing his water project. In fact, 
the North Coast Water Company found itself suing the United States of America in federal court. Intimidated but undaunted, Newlands persisted. The court granted continuances in the case until Kent sold the North Coast Water Company another tract suitable for a reservoir, and Newlands finally withdrew the suit (Rothman 1989, 63).

Satisfied with the alternative reservoir site Newlands made no further efforts to develop Muir Woods. The redwoods remained unharmed and in 1921, Muir Woods' boundaries were expanded to 560 acres. Presently, Muir Woods attracts more than a 1.5 million visitors annually.

The establishment of Muir Woods National Monument set several precedents in the use of the Antiquities Act. It was the first donation of private land for a national monument and it was the first monument with a neighboring metropolis. Muir Woods National Monument protects "an extensive growth of redwood trees (Sequoia sempervirens) of extraordinary scientific interest and importance" (Roosevelt 1908, Proc. No 793). The scientific justification for preservation made Muir Woods National Monument the first monument to protect a natural area rather than a specific feature. Newlands' impending lawsuit threatening the land required immediate action; as a result Muir Woods National Monument was the first monument to be created by an emergency measure. That lawsuit also provided the first controversy preceding the establishment of a national monument. 


\section{GRAND CANYON}

Additional controversy was quick to follow. On January 11, 1908, Teddy

Roosevelt created Grand Canyon National Monument, which covered 808,120 acres.

Unlike the impromptu proclamation to protect Muir Woods, preserving the Grand

Canyon had been a concern of Roosevelt's for several years. Roosevelt first articulated his concerns about commercial development despoiling the canyon in 1903. In May of that year he journeyed to the Grand Canyon and was impressed. In a now famous and often quoted speech he declared that "you can not improve it. The ages have been at work on it and man can only mar it" (quoted in Rothman 1989, 65).

Tourism at the canyon had been increasing since the 1890 s, resulting in the need for lodging and other services for visitors. Against Roosevelt's wishes hotels and shops marred the rim of the canyon. By 1907 developers staking mining claims also threatened to alter the scenic vistas that Roosevelt admired. Roosevelt used the Antiquities Act to protect the Grand Canyon from exploitation by creating Grand Canyon National Monument. The Forest Service was put in charge of the management of the new monument. This put an end to exploitation by private enterprise. Several lawsuits filed by the developers followed. These cases were eventually dismissed in federal court (Rothman 1989).

The establishment of Grand Canyon National Monument showed Roosevelt's willingness to use the Antiquities Act and his executive authority to achieve his goals. Grand Canyon National Monument was the first national monument established with commercial development already in the park. Roosevelt's intervention allowed the 
federal government to control the existing commercial enterprises as well as future development. The monument's size was unprecedented. It remained the largest national monument in the continental United States until 1933 when Death Valley National Monument was created. It also demonstrated the president's ability to control development and exploitation of large tracts of land (Sellars 1997). Converted to Grand Canyon National Park in 1919 , the park now covers over one million acres and is considered a national treasure.

\section{MOUNT OLYMPUS}

Roosevelt used his presidential authority for one final act in 1909 , just days before he was to leave office. His final proclamation protected 639,200 acres of rugged forestland on the Olympic Peninsula of Washington as Mount Olympus National Monument. The plan to create Mount Olympus National Monument was hatched by Washington's Congressman Humphrey. In a single brief meeting Humphrey and Gifford Pinchot (Chief of the United States Forest Service) persuaded Roosevelt to preserve the land in order to protect the Olympic Elk (Cervus roosevelt) which relied on the forest habitat. With Roosevelt's approval Pinchot carved Mount Olympus National Monument from National Forest Service land (Foresta 1984). Opponents considered the monument a "sham to placate the rising national park movement in Seattle and throughout the state," which was orchestrated by Humphrey and Pinchot (Lien 1991, 39). 
The conservationists would be placated, but only at the risk of outraging local forest industry members. Knowing that the monument contained valuable timber resources Pinchot inserted clauses in the proclamation that allowed, and even encouraged, logging to continue (Lien 1991). The establishment of the national monument angered mining and logging developers even though the proclamation did not prohibit resource development. Any potential restrictions on the area's resources were perceived as a threat. Wanting to protect their income potential, the developers demanded an immediate repeal of the monument. Roosevelt's successor, Woodrow Wilson, responded by reducing the area of the park. However, Wilson's Secretary of Interior Richard Ballinger took a strong position that nullified Pinchot's logging clauses. He asserted that the intent of the Antiquities Act in protecting lands from exploitation overrode the clauses in the proclamation. Mount Olympus National Monument was closed to mining and logging. Succeeding attempts to reduce or abolish the monument were unsuccessful. Mount Olympus National Monument was converted to Olympic National Park in 1933 (Lien 1991).

The establishments of Muir Woods, Grand Canyon, and Mt. Olympus National Monuments were shrouded in controversy. However, they did not generate the congressional and legal challenges to the Antiquities Act to the same degree as the following monuments to be considered for case histories. These monuments represent some of the most significant challenges to the Antiquities Act, and different regions of the American West. The first case history discusses Jackson Hole National Monument, established in 1943 in the Rocky Mountain region of the West. The 
second case describes the 1978 proclamations made by Jimmy Carter to protect lands in Alaska. The final case history covers the most recent monument, Grand StaircaseEscalante National Monument, located in the Southwestern United States. Though all are located in very different regions of the West, the case histories will show that the response of the people of these different regions to presidential intervention in land management is similar. 


\section{CASE HISTORY: JACKSON HOLE NATIONAL MONUMENT 1897-1950}

\section{THE LONG BATTLE TO PRESERVE JACKSON HOLE}

Characterized as sudden by the news media, the establishment of Jackson Hole National Monument by Franklin D. Roosevelt on March 15, 1943, was in truth far from impulsive (Saylor 1970). The battle to protect the Jackson Hole area began in the late 1800's. In 1897, Colonel S. D. M. Young, supervisor of Yellowstone National Park, suggested that in order to protect migrating elk the boundaries of Yellowstone should extended to include Jackson Hole (Sanborn 1978). In 1898, Charles D. Walcott, "the director of the United States Geological Survey recommended that Jackson Hole either be added to Yellowstone National Park or be made a separate park, but nothing came of it" (Betts 1978,193).

The struggle between development and preservation began in earnest in the 1900's. Developers made progress when Jackson Lake was dammed in 1906. The water was impounded to irrigate the arid lands of the Snake River Basin of Idaho. Local Stephen N. Leek won one of the first conservation victories. He helped lead the effort to help protect the valley's wildlife. Through his efforts the National Elk Refuge was established in Jackson Hole in 1912 (Calkins 1973).

It was not until 1918 that congress became involved in the Jackson Hole preservation issue, when Wyoming Senator Frank Mondell introduced a bill to extend the boundaries of Yellowstone National Park. The proposed extension included the 
Teton Range and the northern end of Jackson Hole. Mondell's bill passed easily in the House of Representatives but was stopped in the Senate by Idaho Senator John Nugent. Nugent's actions were in response to his sheep-raising constituents on the western side of the Tetons. They were concerned that the proposed park would jeopardize their grazing rights (Saylor 1970).

With his near success at passing the bill in 1918, Mondell reintroduced the bill in 1919. The newly appointed Superintendent of Yellowstone National Park, Horace Albright, lent his support to the campaign to pass the bill (Calkins 1973). This time the bill met opposition even before reaching the floor for a vote. The Wyoming legislature passed a resolution opposing the extension of Yellowstone's boundaries (Albright 1933). Citizens in Jackson Hole spoke out against the bill. Dude ranchers, cattlemen and Forest Service employees opposed the bill. The dude ranchers were concerned that the influx of tourists brought by the new park would ruin the romantic old-west feel of the valley; new hotels, roads, tourist attractions and the bustle of automobiles would destroy the atmosphere that brought guests to their ranches. The cattlemen saw the park as a threat to their grazing rights. The Forest Service employees thought the new park would take land from the Forest Service rolls, and eventually take their jobs (Saylor 1970). Such strong opposition forced Mondell to withdraw his bill (Betts 1978).

In the early1920's the tide of public opinion changed. The change was due to more threats to the valley's charm (Albright 1933). Despite resistance from the valley's residents, tourists began to invade Jackson Hole. Facilities were built to cater 
to the influx of tourists. Some locals took advantage of outsider interest and sold their land in order to survive the harsh economic conditions brought on by a drop in demand for beef.

The pressure of resource development also increased. A private company filed with the Wyoming government to dam two lakes at the flank of the Tetons: Jenny Lake and Leigh Lake. The dam builders aspired to use the lakes' water for irrigation in Idaho (Sanborn 1978). Not only would the two lakes be altered, but also canals cut to transport the water would scar the valley. With these threats the ranchers allied themselves with Albright and the National Park Service (Calkins 1973).

By 1923 development pressure made valley residents anxious enough to take action to preserve the character of Jackson Hole (Boyd 1945). A group of residents approached the federal government with a proposal to create Jackson Hole National Recreation Area. Though supported in word by many, few supported the idea with funds. The proposal never made it to congress, but it is significant in showing the local interest in preserving the area (Sanborn 1978).

The seesaw between development and preservation continued through the 1920s and 1930s. In 1925 the Forest Service considered issuing mining permits in the valley and planned to issue permits allowing logging on the shores of Jackson Lake. In response the locals circulated a petition to revive their recreation area plan. An overwhelming ninety-seven percent of the residents signed the petition. No recreation area was established, but the plans to log and mine in the forest were terminated. Once again the locals had expressed a strong desire to protect their valley. 
With increased development came more visitors. Many of them were impressed with the area. One such visitor was John D. Rockefeller, Jr. His visit to Jackson Hole in July of 1926 was the catalyst for another plan to protect the area. With the assistance of Horace Albright, Rockefeller devised a plan to purchase tracts of land in the valley and then deed the land to the federal government for use as a national park. Their goal was to purchase approximately 100,000 acres from over 400 different landowners. The estimated cost was over $\$ 1,000,000$ (Betts 1978).

Concerned that news of the plan would inflate property prices Albright advised Rockefeller to keep the plan a secret. Rockefeller agreed and formed the Snake River Land Company. Some government officials in Washington were notified of the plan, but even the attorney hired to form and advise the new company was unaware of the plan and the man behind the funding. By the end of 1927 the Snake River Land Company was actively acquiring lands in the valley.

By 1929 the effort to preserve the Tetons was gaining momentum. Wyoming Senator John Kendrick backed another bill in congress to create a new national park protecting the Teton Mountains and the lakes at its base (Calkins 1973). The locals attending the Senate subcommittee meeting in Jackson voiced overwhelming approval of the new park. Grand Teton National Park was created. (See Figure 2) The land on the eastern side of the mountains was transferred from the Forest Service to the National Park Service with little fanfare or opposition.

Though the creation of Grand Teton National Park went smoothly, it did raise suspicions about the Snake River Land Company's motives (Betts 1978). The fears of 
some locals were confirmed in 1930 when it was revealed that Rockefeller was behind the Snake River Land Company and that the lands held by the company were being bought for eventual transfer to the federal government (Saturday Evening Post 1943). The public's response was divided (Sanborn 1978). Some saw the prospect of adding the valley to the National Park Service as beneficial to the area's economy. Others were bitterly opposed. Cattlemen and sportsmen predicted limits to their grazing and hunting rights. Some thought they had been tricked into selling their land for less than top dollar. Forest Service employees, once again, opposed the possible loss of Forest Service lands to the National Park Service. Wyoming's two senators called for a Senate inquiry. Hearings were held in Jackson in 1933. The Senate committee found that the transactions were fair and that many landowners had received prices exceeding fair market value.

For the next ten years all attempts to settle the issue were in vain. Bills ranging from the acceptance of the Rockefeller land, to the abolition of Grand Teton National Park were unable to pass in congress. This stalemate especially frustrated Rockefeller (Saylor 1970). He had made an enormous investment, spending over $\$ 1,400,000$ to purchase over 35,000 acres, and was paying $\$ 13,000$ annually in taxes on that property (Rothman 1982; Calkins 1973). Having reached the end of his patience in November 1942 he sent a letter to Harold Ickes, the Secretary of the Interior. The letter notified the federal government that Rockefeller planned to dispose of the property by whatever means possible by the end of 1943 (Boyd 1945). 
It was not clear whether Rockefeller's letter was a bluff to instigate action, but Ickes and Roosevelt took it seriously. Without Rockefeller's land the dream of protecting Jackson Hole for future generations was in danger. Ickes took action. He persuaded Roosevelt to use the Antiquities Act to protect the valley. On March 15, 1943 Jackson Hole National Monument was created by presidential proclamation. (See Figure 3) The new monument consisted of 221,610 acres: seventy-seven percent federal land, fourteen percent Snake River Land Company lands, eight percent private lands, and one percent state land (Audubon 1944). (See Table IV.) 
TABLE IV

THE SOURCE OF LANDS AND AMOUNT OF ACREAGE ASSEMBLED TO CREATE JACKSON HOLE NATIONAL MONUMENT SOURCE: RIGHTER 1982, AUDUBON 1944

\begin{tabular}{|l|cc|}
\hline Source of acreage & \# of acres & $\%$ of total \\
\hline National Forest Service lands & 99,345 & $45 \%$ \\
\hline Water surface & 31,640 & $14 \%$ \\
\hline Public domain & 39,323 & $18 \%$ \\
\hline State lands & 1,406 & $1 \%$ \\
\hline Private lands & 17,779 & $8 \%$ \\
\hline SRLC lands & 32,117 & $14 \%$ \\
\hline Total acreage & 221,610 & $100 \%$ \\
\hline
\end{tabular}




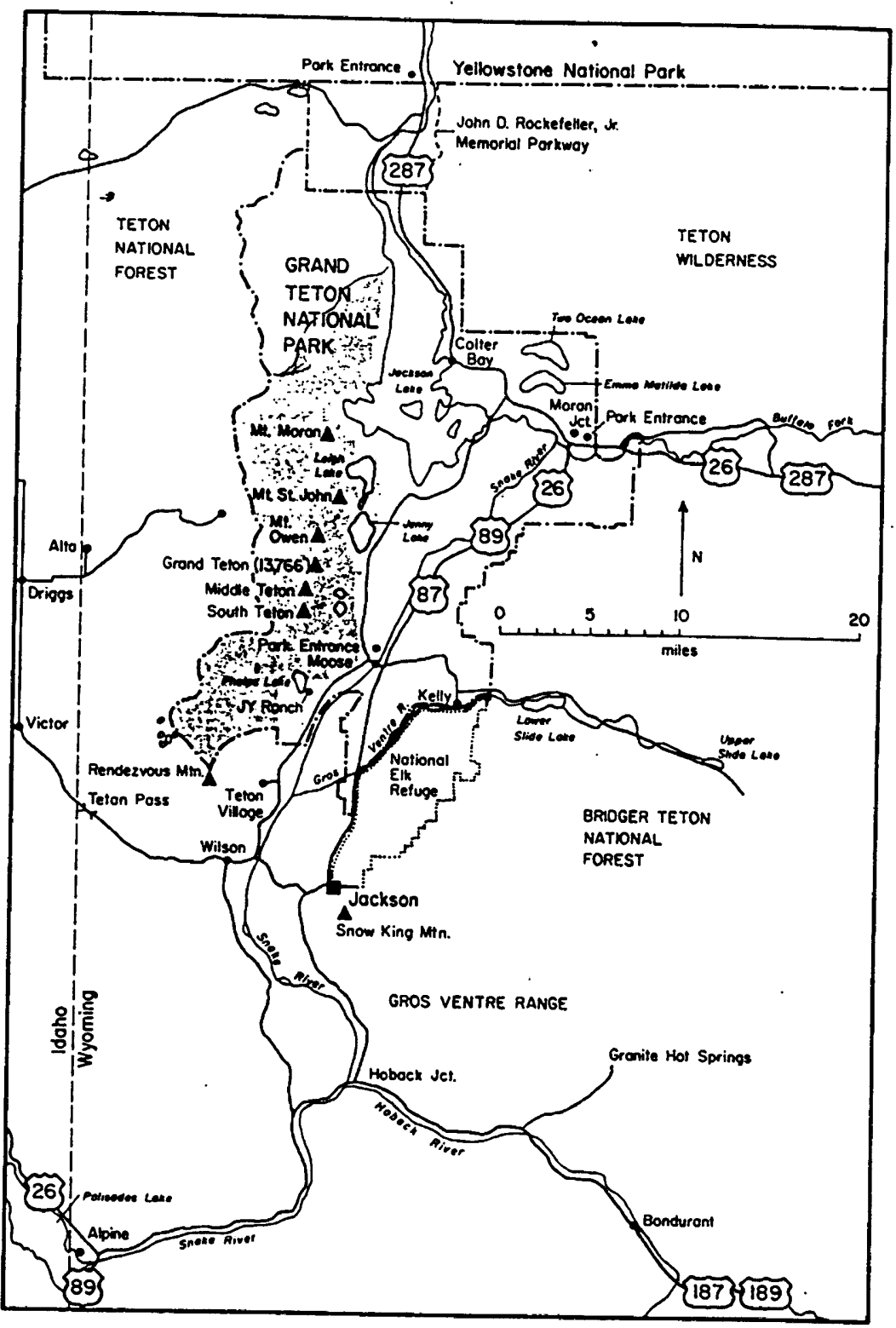

Figure 2. Map of Grand Teton National Park as established in 1929. (Source: Righter 1982, 41.) 


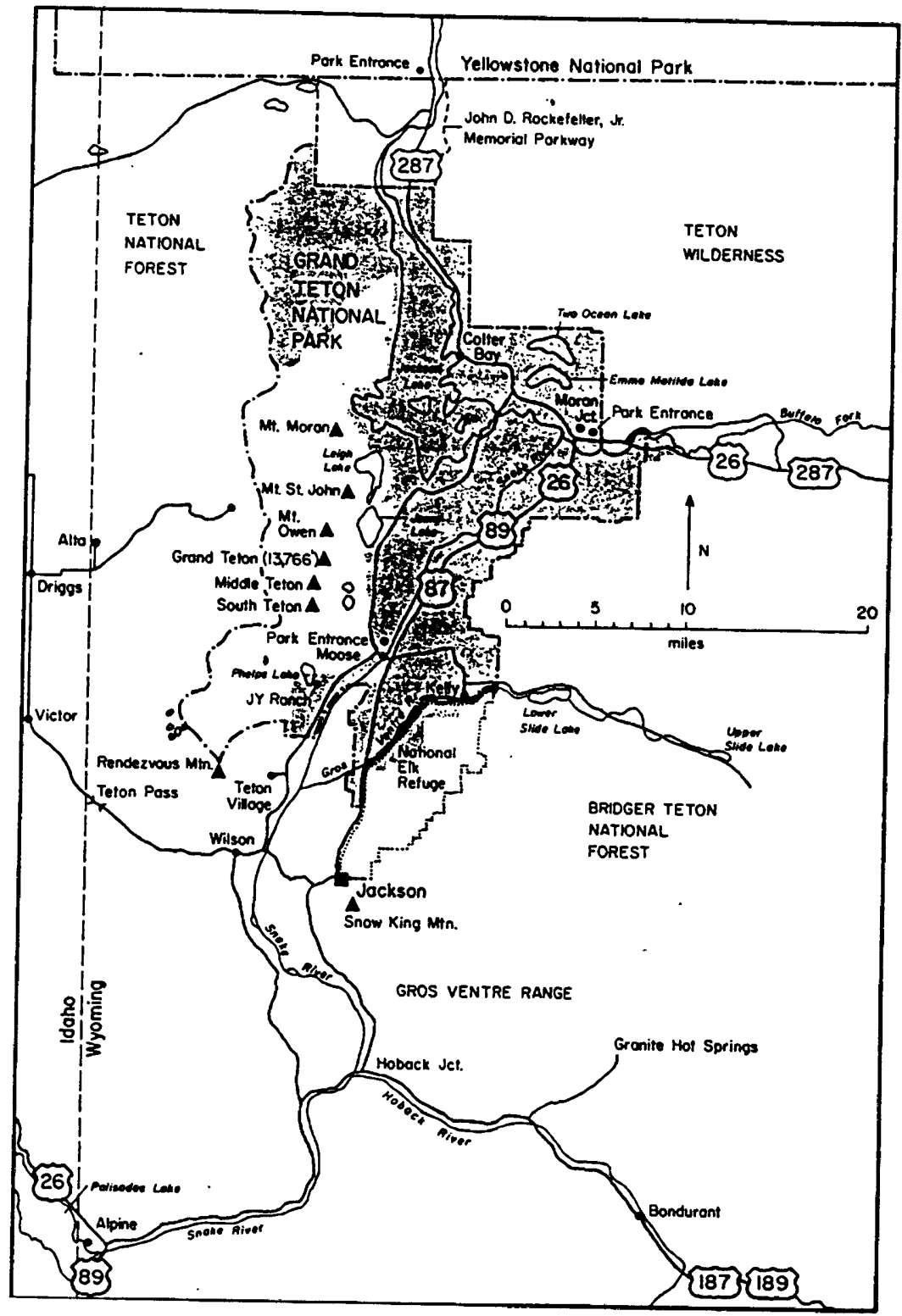

Figure 3. Map of Jackson Hole National Monument as established in 1943. (Source: Righter 1982, 112.) 


\section{THE PUBLIC RESPONDS}

Rockefeller was relieved that the park would finally become reality (Righter 1982). Conservation groups praised Franklin Roosevelt's bold action (Audubon 1944). However, even though many conservation groups supported the preservation of the Jackson Hole lands, they did not favor its inclusion in the National Park system. For a number of reasons Jackson Hole was considered below the standards of the country's other National Parks (Miles 1995). Several features in the park troubled National Park purists. Man-made Jackson Lake and irrigation developments were not viewed as suitable features for a National Park. Some park advocates were afraid that these features would set a precedent, encouraging developers to pursue dam building and irrigation in other parks. In addition the sagebrush plain in the valley was considered quite common and not becoming of the National Park image (Nature Magazine 1943; Righter 1982). Conservationists did agree that Jackson Hole needed protecting, even if they did not agree that the National Park Service was the right agency to protect it.

Outside of conservation circles the reaction to Roosevelt's proclamation created a chorus of disapproval (Sanborn 1978). Since Rockefeller's ultimatum was not publicized immediately, Roosevelt's proclamation surprised many Jackson Hole residents (Saylor 1970). The groups and individuals that were opposed to the federal government's intervention were even more outspoken following the creation of the national monument. Property owners, ranchers, politicians and local newspapers joined in an effort to protest the new monument. 
Protests were not necessarily in response to the preservation of Jackson Hole, but to the president's autocratic action. The reasons for disapproval were many. One concern was that wealthy outsiders/easterners were interfering with their western way of life. Claims of states' rights violations were voiced. The president was accused of exceeding authorized constitutional powers. Worries over lost tax revenue and lost grazing privileges were expressed. Not all of these concerns proved to be true.

Jackson Hole residents were no different from other westerners in resenting land management decisions made by outsiders. They believed they were the ones who knew the land best, and would make the best decisions (Saylor 1970). In Jackson Hole the sentiments against easterners were not just based on this typical east-west dialectic. This time the interloper had a name: John D. Rockefeller, Jr. Some of the anger was directed at the covert land buying operations of the Snake River Land Company. The secrecy that surrounded the first year of land purchases raised suspicion of the valley residents. There was also a perception that what Rockefeller wanted, he got. They resented him and his family's power, his money, and his arrogance (Calkins 1973).

The situation in Jackson Hole served to put a spotlight on the Antiquities Act's alleged violation of states' rights. Governor Hunt considered the integrity of the state to be at stake. The Jackson Hole residents were presented as "the last of the rugged individualists doing battle with ... Washington bureaucrats" (Righter 1982, 111). The state of Wyoming was concerned about its "investment in the property, 
including highways, game animals, and birds" (Rothman 1989, 215). Also, not one state official was consulted in the planning or drafting of the proclamation creating the new monument. Even though only 1 percent of the area in the monument was state land, state officials were angered that Wyoming lands were appropriated without their input (Rothman 1989).

Another controversial aspect of the Antiquities Act, raised in response to the creation of the monument, deals with the limits of presidential power. The protection of Jackson Hole was an issue that had failed to gain congressional approval, even though many of the landowners in the valley pleaded with the government to protect the area. Roosevelt's interference was not solicited by the locals and was perceived as an inappropriate use of presidential power. The president's usurpation of congress and citizen participation angered preservation advocates and opponents.

Citizens and elected officials condemned Roosevelt's use of power. Congressman Joseph O'Mahoney of Wyoming viewed the executive order as a "taking" and claimed Roosevelt's executive decree was made to "accomplish an objective which could not be accomplished by legislative action. "(New York Times 1943, 12). In response to the proclamation the Saturday Evening Post remarked that the United States' motto "E Pluribus Unum" should be changed to "Never Give a Sucker an Even Break"(Saturday Evening Post 1943, 100). Even Thomas Dewey, while campaigning for president in 1944 , vilified the proclamation, stating that it was against the wishes of the people of Wyoming (New York Times 1944c). 
Grazing privileges and loss of income from tax revenue were two of the underlying concerns voiced by the people of Wyoming. The 1943 proclamation did not address existing grazing rights on the lands within the new monument. However, it was the intention of the government and Rockefeller to allow grazing to continue as it would not compromise the character of the valley. In fact, the conditions set by Rockefeller in his plans regarding the donation of the Snake River Land Company lands included a provision to provide grazing rights for ranchers currently using the land (Webb 1933).

Over 170,000 acres of the 221,610 acres of the new monument were federal lands and had never provided tax income to the state of Wyoming (New York Times 1944c). The state and Teton County, however, still made their objections clear. They wanted compensation for the loss of tax revenue. The estimated loss of taxes was $\$ 13,000$ annually on the Rockefeller donation and $\$ 8,750$ annually on other private lands included in the monument. As with the grazing rights, Rockefeller made recommendations for compensating Wyoming and Teton County for lost revenue (Webb 1933). The federal government also supported reimbursement, and publicly confirmed their commitment to provide for lost tax income by July of 1944 . Despite the allowances for compensation objections to the potential loss were still used as ammunition to condemn Roosevelt's actions.

Not all of the valley's residents were angered by the proclamation. According to Betts the controversy turned friends and neighbors against each other. The debate became so heated that "some people even stopped speaking to each other, 
Forest Service facilities were literally cleaned-out under the direction of Teton National Forest Supervisor, F. C. Kozol. All furniture, equipment, plumbing fixtures, kitchen appliances, doors, cabinets, and even an underground water tank were removed. Kozol's actions left the station uninhabitable. Regional Forester C. N. Woods disciplined Kozol. While showing lack of approval for Kozol's methods, Woods, however, voiced his support for Kozol's motivation. He made a statement notifying Washington that the National Forest Service wanted to be consulted before it made any future concessions to the National Park Service (Righter 1982).

The governor of Wyoming, Lester Hunt, joined the ranchers and Forest Service in showing his disapproval. Governor Hunt vowed to use force to oust from the monument, any federal employee who tried to assume authority (Betts1978; Righter, 1982). Appealing to the president, he also asked him to rescind the proclamation. Governors of six other western states took up the cry against the new national monument. During the Western Governor's Conference in April 1943, the six governors and Governor Hunt passed a resolution condemning Roosevelt's actions. The governor of California, Earl Warren, proposed drafting a bill that would repeal the Antiquities Act, but it lacked adequate support form the other governors to make it to congress (Righter, 1982). Despite this political pressure the president stood his ground.

Newspapers and magazines, like the citizens of Jackson Hole, were on both sides of the issue. The Jackson Hole Courier's editorial staff supported the new monument in contrast to some of its readers who provided plenty of negative 
opinions through letters to the editors. The Casper Tribune-Herald also supported the monument. It advised readers that even before Rockefeller's land purchases the valley's quality had been declining because of uncontrolled development. Now the structures detracting from the valley's beauty would not be permitted (Betts, 1978).

Newspapers around the country showed support for the monument (Saylor, 1970). In contrast, the Jackson Grand Teton was created to voice opposition to preservation efforts (Calkins, 1973). The Saturday Evening Post, normally in favor of conservation efforts, was a firm opponent to Jackson Hole National Monument because of the tactics used to create the park. Syndicated columnist Westbrook Pegler compared Roosevelt's actions to Hitler's occupation of Austria (Saturday Evening Post, 1943).

The fight against Jackson Hole National Monument was more than verbal barrages and civil disobedience. Congressmen from Wyoming and Nevada sought legislative action to reverse the president's proclamation. Two bills were introduced: one to abolish the new monument, the other to repeal the Antiquities Act. Frank Barrett of Wyoming introduced H.R. 2241 to congress by May, 1943. The bill, known as the Barrett Bill, would abolish the monument if it passed and was signed by Roosevelt. The bill was in committee by early June, and in mid August congressional testimony was taken in Jackson, Wyoming. Most of the testimony was in support of the Barrett Bill. Over 650 people present at the testimony stood in a vote to abolish Jackson Hole National Monument. Six people remained seated, and presumably lacked the courage to stand for a vote against the bill. In 1945 the 
Barrett Bill reached the House of Representatives for a vote. It passed with 178 voted in favor, 107 voted against and 142 abstained. The Senate passed the bill unanimously: no arguments and no roll call. Roosevelt, however, vetoed H.R. 2241 (Righter, 1982).

The bill to repeal the Antiquities Act, S. 1046, was co-sponsored in congress by Joseph O'Mahoney of Wyoming and Pat McCarran of Nevada. This bill died in committee, but O'Mahoney applied other methods to threaten the existence of the new monument. From 1943 through 1945 he included an amendment in the Appropriations Act which prohibited funding for Jackson Hole National Monument. Without funds the administration and protection of the monument was limited to the standards in effect before Roosevelt's proclamation (Saylor, 1970; Betts, 1978).

Jackson Hole National Monument was also challenged in federal court. The state of Wyoming filed suit on May 18, 1943. Their case attacked the President's authority to use the Antiquities Act on Jackson Hole lands, and the ambiguity of the Act. Testimony was heard from both sides in August 1944. Strangely, Judge T. Blake Kennedy, dismissed the case after all evidence was presented. His February 1945 ruling stated that the controversy was between the executive and legislative branches of the government, and the judicial branch should not intervene. This was considered a victory for the defendant (Rothman 1989; Saylor, 1970).

Jackson Hole National Monument thus withstood challenges in congress, in court and in the streets. As time passed the objections to the monument diminished. Although Barrett, O'Mahoney, and other Wyoming congressmen sustained the fight 
against Jackson Hole National Monument and the Antiquities Act, they continued to lose support in Jackson Hole and around the country. Gradually they realized that their efforts were useless and began to focus on resolving the conflict. Even Governor Hunt expressed his desire to see the conflict end (Betts, 1978). Seven years after Roosevelt's proclamation congress turned to the task of providing for the administration and management of the monument.

In the years following the establishment of Jackson Hole National Monument the mood began to change. Franklin Roosevelt died in 1945, and much of the anger over his use of power faded. Conservation groups gained momentum, while the number opponents decreased (Righter, 1982). In 1948, former Governor Hunt was elected to congress. By this time Senators O'Mahoney and Barrett who had fought so diligently to abolish the monument began to realize the need to compromise. Hunt along with O’Mahoney sponsored a bill to incorporate Jackson Hole National Monument into Grand Teton National Park. On September 14, 1950, President Truman signed the bill into law (Saylor, 1970).

The opponents of the monument and the Antiquities Act did have a small victory. The 1950 act specifically permitted uses not allowed in Grand Teton National Park and many other national parks. The building of roads and hotels was allowed, as well as grazing (Calkins 1973). The greatest victory for O’Mahoney, however, was an attachment to the bill, which would amend the Antiquities Act. The amendment prohibited the establishment or extension of any national monuments in Wyoming without congressional approval. 
As a result of the debate over Jackson Hole National Monument the Antiquities Act was amended to limit the use of presidential power. The conflict also set a tone that was significant in limiting the use of the Antiquities Act. By denying funding to monuments that lacked congressional approval, congress could stifle the use of the Antiquities Act. After Jackson Hole most monuments were established only with reassurance that congress would approve funds to administer and maintain the monument (Rothman, 1989). 


\section{CASE HISTORY: PROTECTION OF ALASKA D-2 LANDS 1971-1980}

\section{CARTER'S BOLD MOVE}

After Franklin Roosevelt's battles with congress, and the public outcry over Jackson Hole, the use of the Antiquities Act decreased (Rothman 1989). Contrary to this trend, Jimmy Carter used the Act, on December 1, 1978, in an unprecedented way to create fifteen new national monuments and expand two existing monuments. Almost 56 million acres were withdrawn from the public domain on that one day.

Carter's December 1, 1978, proclamations were in response to a deadline set some years earlier. On December 18, 1971, congress passed the Alaskan Native Claims Settlement Act (ANSCA). Section 17d-2 of ANSCA authorized the Secretary of the Interior to recommend up to 80 million acres of Alaska's public land (d-2 lands) as permanent federal reservations. The law gave the Secretary seven years to get his land selection approved by congress. Finally, in 1973 the Secretary of the Interior under Richard Nixon, Rogers B. Morton, recommended 32.2 million acres for inclusion in the national park system. Now it was up to congress to pass a bill approving his proposal.

Between 1973 and 1977 no progress was made in getting a bill passed. Members of congress could not agree on how much land should be permanently reserved or who should manage the lands in question. In 1977, three bills were introduced into congress, each representing a different interest group. Representative 
Morris K. Udall of Arizona introduced H.R.39, which proposed reserving 116 million acres. All of the proposed land would be classified as wilderness. Contrasting Udall's bill was S.1781 sponsored by Alaskan Senator Ted Stevens. This bill represented the view of the Alaska State government and proposed withdrawing 25 million acres from the public domain with no wilderness designations. The Carter administration provided the third bill that would set aside 92 million acres, 43 million of that to be wilderness.

In May of 1978, the House passed H.R. 39, but not before the bill was modified in committee. When approved, H.R. 39 proposed 100 million acres of reservation, including 66 million acres of wilderness. Though passing the House 277 to 31 , the bill failed to obtain Senate approval because of actions to block the bill by the two Alaskan Senators, Mike Gravel and Ted Stevens. It appeared that the congressional session would end without the Senate voting on the bill. Without congressional approval the lands would revert to state control on December 18, 1978. Attempts to get an extension bill through congress were also blocked by Senator Gravel.

With the deadline approaching the executive branch took action. In November 1978, Cecil Andrus, Carter's Secretary of the Interior, was directed to use authority provided by the Federal Land Policy Management Act to make an emergency withdrawal of 110 million acres. In addition, Andrus also established forty million acres of wildlife refuge. Also in response to the president's orders, 11 million acres were closed to mining by the Secretary of Agriculture (Cooley 1984). Though these 
withdrawals would expire in three years, they could still give congress more time to agree on legislation. Even with the protection allowed through Federal Land Policy Management Act, Carter issued his own proclamations, protecting over 56 million acres covering 17 different sites as national monuments.

The significance of Carter's proclamation is threefold (1) congress had not approved funding for the monuments prior to the proclamations, (2) the Antiquities Act was used as an emergency measure, and (3) the monuments created were the largest ever.

The issue of funding for the new monuments was only of slight concern for Carter. The lands needed to be protected from development and land claims, not developed for park visitors. Most of the lands were very remote and inaccessible (Rothman 1989). Money to pay for infrastructure and personnel was not necessary. Carter also expected congress to come to an agreement on H.R. 39 in the next congressional session. He merely granted them additional time to reach a decision.

This was not the first time that a president had created a large monument as an emergency measure. Teddy Roosevelt's establishment of the Grand Canyon National Monument comes to mind. It was, however, the first time since Franklin Roosevelt's conflict over Jackson Hole National Monument that a president had exercised his power to protect such extensive acreage. Carter stated in his December 1 proclamation, "Because of the risks of immediate damage to these magnificent areas, I felt it was imperative to protect all of these lands and preserve for the congress a unhampered opportunity to act next year" Carter 1979). 
It is clear from this statement that Carter's intention was to prevent the lands from reverting to state control, thus allowing congress more time to work out a solution for the protection of the lands. Carter believed that National Parks, Wildlife Refuges, Wilderness Areas, and Wild and Scenic Rivers were a high priority. The introductory sentence of his statement says,

As our people have spread across the continent and the needs for development reach once distant frontiers, we realize how urgent it is to preserve our heritage for future generations. (Carter 1979)

$\mathrm{He}$ also believed that he had support in congress for legislation protecting that heritage and along with it, the environment.

Protecting the environment is not one of the mandates included in the Antiquities Act. However, the Alaska monuments contained unquestionable scientific, historic, or archaeological value that met the Act's criteria for protection. The monuments' size left the monuments vulnerable to critics by testing the limits of the Act's "smallest area" principle. Unlike Muir Woods, Grand Canyon, Mount Olympus, and Jackson Hole, the d-2 lands covered millions of acres in seventeen separate sites across the state. The smallest of the new monuments was 350,000 acres, the largest 10,950,000 acres. (See Figure 4.) Protection advocates claimed that it would be possible for Congress to set aside a large amount of area (totaling a very impressive acreage figure for those accustomed to dealing with the smaller scale of the other 49 states) without doing very much to protect the wildlife, rivers and lowlands that should be the focus of the legislation. We must keep in mind that nearly onethird of the acreage now in national park system status is snowcovered mountains and glaciers over which there is no controversy. Although these mountains are spectacularly scenic, placing 15 million acres of peaks in parks will do nothing to protect the valleys and 
forelands where the wildlife and recreational opportunities of interest to most park visitors are found" (U.S. Code $96^{\text {th }}$ Congress Volume 5 1980, 5316).

Some years later the question of appropriate size would reappear with the establishment of Grand Staircase-Escalante National Monument.

\section{PUBLIC RESPONSE TO THE PRESIDENT CARTER'S ACTIONS}

The response to Carter's proclamations was magnified by several economic and political circumstances. The United States was in the middle of an oil crisis. Prices for petroleum products were at an all-time high. American's frustrated with high prices and long gas lines, looked to Alaska and its oil reserves for relief. The prospect of tapping oil reserves in Alaska created economic optimism and hopes for lowering unemployment rates. In 1978 Alaska's unemployment rate of 12 percent was one of the highest in the country. Alaskans believed that developing oil and other natural resources was the key to a healthier economy.

Alaskans were also not entirely satisfied with the federal government. The 1958 Statehood Act promised to Alaska title to over 103,000,000 acres of public lands. The selection of these lands had not been reconciled by 1978 , and continued to create conflict between the state, Native Americans and the federal government (U.S. Code and Administrative News $92^{\text {nd }}$ Congress, 1971 v2). In addition, the State Constitution of Alaska mandates the development of natural resources to sustain Alaska's economy (Commonwealth North Federal-State Relations Committee, 1990). 


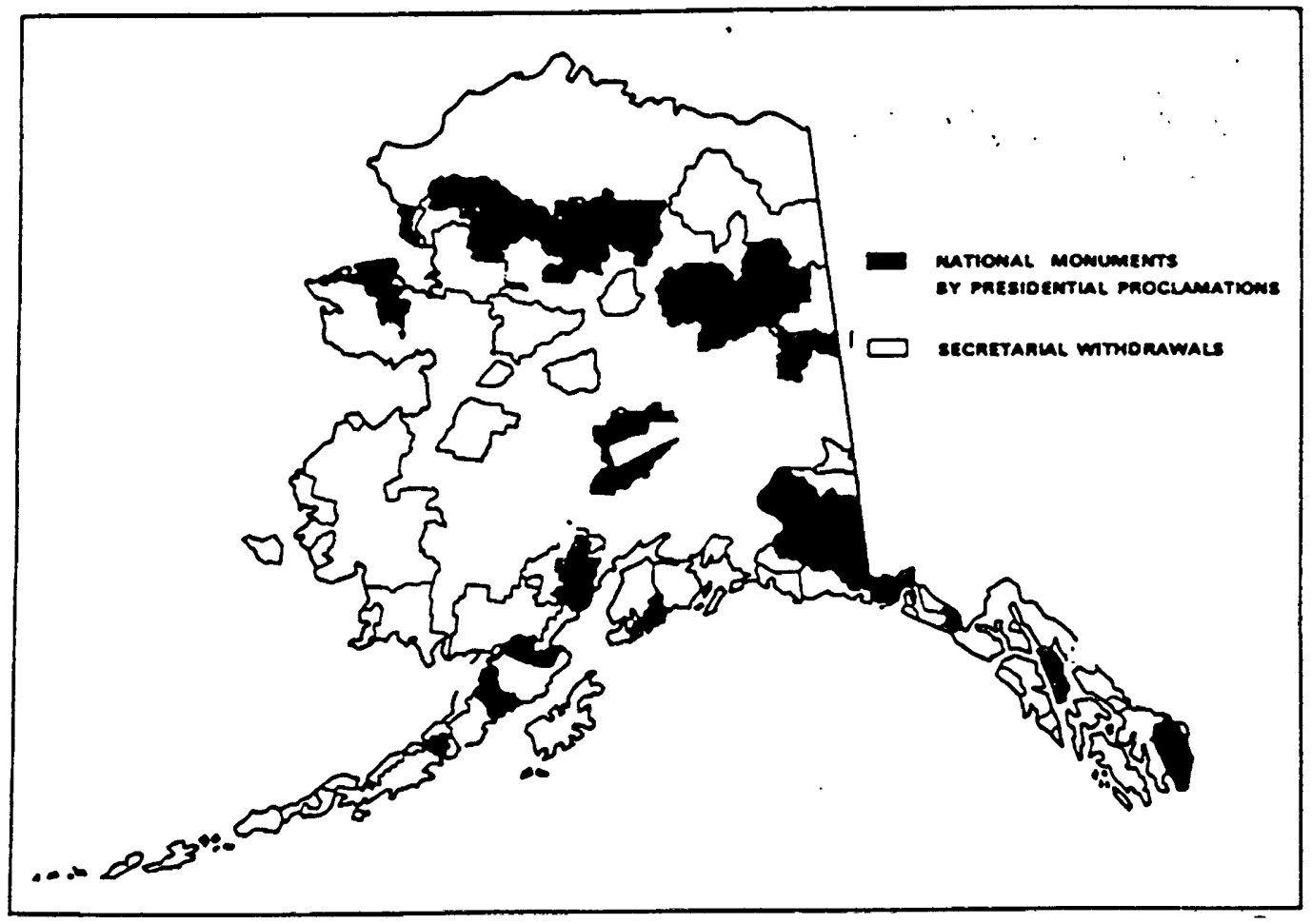

Figure 4. Map of Alaska showing lands withdrawn by the President, as national monuments, and by the Secretary of the Interior in 1978. (Source: Congressional Quarterly Almanac 1978, 741) 
Carter's election to office in 1977 created more concerns in the West, including Alaska. Carter was viewed as an opponent to western interests and development rights. Not one western state carried the new president in the election. The West's rejection of Carter became more resolute when, during his first year in office, he cut funding from eight western water projects. The water projects listed by Carter were compiled without consulting citizens or congressmen. He was criticized for eliminating public participation and denying state's rights. This action furthered the belief that Carter was either unaware of the West's needs, or was antagonistic towards them (McGreggor 1993).

Alaska and the West were clearly opposed to the Carter administration and the efforts of congress to protect Alaskan wilderness. After H.R. 39 passed in the House in 1978, angry opponents concerned about stifled economic growth, lashed out at the legislation. Both of Alaska's Senators vowed to kill the bill. The tone in Alaska was referred to as a "mood of militancy" in a normally "easy-going state" (U.S. News and World Report 1978, 61). An estimated 67 percent of the state's 407,000 residents opposed H.R. 39. Even prior to the passage of the bill and Carter's proclamation, citizens were threatening to withdrawal Alaska from the United States (U.S. News and World Report 1978).

In early October 1978, the Department of the Interior released an Environmental Impact Statement disclosing its options for protecting the d-2 lands. One of the methods outlined was the use of the Antiquities Act. The State of Alaska reacted by filing suit in federal district court. Their lawsuit sought an injunction to 
prevent the creation of any national monuments. It questioned the use of the Antiquities Act on the Alaska d-2 lands. State officials offered the Carter administration a compromise in early November. It proposed postponing the lawsuit if Carter promised not to employ the Antiquities Act. Carter rejected the proposal on November 17, 1978 (Congressional Quarterly Almanac, 1978).

When Carter's proclamations were announced on December 1, 1978, Alaskans were outraged. They expressed their discontent through the media and legal system. Many showed their lack of approval with civil disobedience. As many as twentyseven different lawsuits were filed (Forbes, 1979). Most of the lawsuits were directed at revoking national monument status, or attacking the Antiquities Act. In addition, Governor Jay Hammond sued the federal government for breaching promises made in the Alaska Statehood Act. The Governor and other Alaska citizens believed the federal government had not delivered the lands it had promised and feared they would never receive those lands.

Citizens not satisfied with pursuing action through the federal courts circulated petitions that called for the secession of Alaska from the Untied States. Others lashed out at federal employees. In Bettles, near the Gates of the Arctic National Monument, residents circulated a petition demanding that all National Park Service employees leave town. The Eagle City Council voted to disobey any park regulations and threatened to trespass on the new park lands (McGreggor, 1993).

Protests against the new monuments were held throughout the state. In Fairbanks, the president was burned in effigy on December 9, 1978. The federal 
courthouse in Anchorage had pickets for four days. In Cantwell, 2500 people participated in a demonstration, claiming the president had violated the Declaration of Independence by denying its promise of life, liberty, and the pursuit of happiness. In one of the new national monuments over 1500 demonstrators protested the monument by building a bonfire. The protests continued well into 1979 . On July 2, 1979, the State of Alaska published a full-page ad in the New York Times expressing their views. The ad complained that Alaska had not received all lands promised at statehood. The ad demanded that Alaska had the right to manage its lands, fish, and wildlife without federal interference. It ordered access and title to all lands and demanded that the President's proclamations be overturned (New York Times, 1979b).

The response of the Alaskan opponents was based on several elements. One concern was that the Antiquities Act was either not legal, or that the intent of the law had been exceeded. Senator Mike Gravel of Alaska expressed this opinion at length, in a letter to the Editor of the New York Times. In his letter he (1)claimed the president overstepped the intent of the law, (2) questioned that the size of the monuments was confined to the smallest area compatible, (3) stated that there was no emergency suggesting the use of the Antiquities Act, and (4) claimed the president's action was inappropriate (New York Times 1979a).

Another cause of protest was the perceived threat to individual rights. The use of executive power excludes the public from the decision-making process. Many Alaskans, including Governor Hammond, felt their independence was threatened. Alaska resident, Ron Anderson, who lived on a 160-acre homestead near the 
Wrangell-St. Elias monument, stated 'the government is simply getting too much power, without land in private hands we're nothing but slaves. Land and guns! If they take those away, we're nothing. If the government surrounds us with parkland, we won't even be able to breathe on it" (quoted in Atlantic Monthly 1979, 484). The myth of the rugged individualist is a crucial aspect of the Alaskan identity. Alaskans want to do things for themselves, and reject outside interference (Schliefelbein, 1979). Politicians representing Alaska's citizens voiced anti-preservation sentiments prior to Carter's proclamation. Carter's December 1 proclamations were an usurpation of those opinions.

The perceived threat to jobs and the Alaskan economy comprised another component of the controversy. Not only did the new parks potentially limit hunting rights, but they also limited other resource extraction. Logging, mining, and drilling operations were prohibited in the new monuments. In addition, the protected lands compromised access to mines and logging operations outside of the monument boundaries. The national monuments blocked access to 3 million acres of Bristol Bay Native Corporation's (BBNC) mining and oil lands, essentially closing them to development. Other lands belonging to other corporations were blocked as well. That land meant jobs and income for the people of Alaska. The executive Vice President of BBNC filed suit against the federal government. Sentiments expressing concern for jobs and antagonism towards preservation are exemplified by the words of Stuart Ramstad who stated, "They want food for the soul. We need food for the body" (McBride 1979). 
When congress reconvened in 1979 it had the authority and opportunity to reduce or revoke the national monuments created by Carter. Despite the response of the public and Alaskan politicians to the proclamation, H.R. 39 was passed in 1980. Support for the preservation of Alaska's wilderness was came from conservationists, some Alaskan citizens, and influential members of congress. Buster Doirone, Alaska fisherman and former logger, traveled to Washington, D. C. to lobby the Senate to pass H.R. 39. He explained his commitment to the cause,

Alaska is our last chance to do what is moral as a human race. Other forms of life have a right to exist. I've got a conscience, and in this case there is a moral right and wrong. It's too bad that people like us have to come down here to protect Alaska from its own senators. They're telling Congress that only the Lower 48 support the d-2 land bill. They're lying. I support it (quoted in Atlantic Monthly 1979, 85).

Representative John Seiberling, (an Ohio Democrat) Chairman of the House Interior Committee's Alaska Lands Subcommittee, believed

if we put land in wilderness, or a national park, or a refuge, that is not an irreversible decision, ... [b]ut if we cut all the timber, the wilderness is gone, and if we dig out all the minerals, they're gone (quoted in Congressional Quarterly Almanac 1978, 730).

The efforts of wilderness supporters prevailed when final d-2 legislation upgraded six monuments to National Park status, converted two monuments to National Wildlife Preserves, and converted one to a National Reserve. Of those monuments that maintained monument status, only two had their area decreased. (See Table V.) 
TABLE V

NATIONAL MONUMENTS ESTABLISHED BY JIMMY CARTER IN 1978 AND THEIR CURRENT STATUS

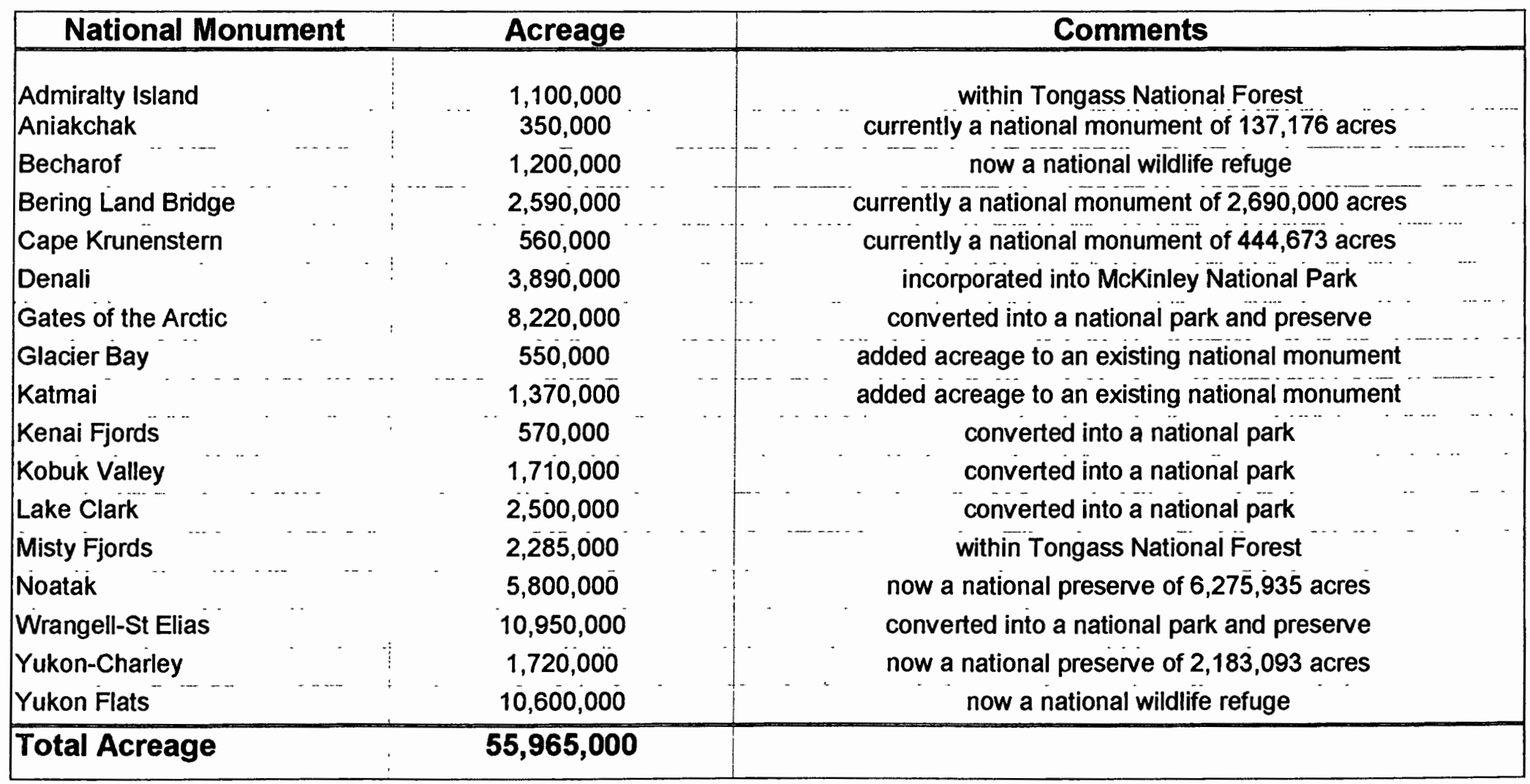


Once again the Antiquities Act and the president's use of power withstood legal and political challenges. As in the case of Jackson Hole, the old guard failed to reverse the president's proclamation. The issues were so hotly contested in these cases, in part, because of the president's usurpation of a congressional stalemate. Eventually opposition decreased, and monument advocates gained support from farsighted individuals in the state and around the country. As time passed the issue faded from the national spotlight the monuments came to be counted among America's national treasures. 


\section{CASE HISTORY: GRAND STAIRCASE-ESCALANTE NATIONAL MONUMENT 1995-1998}

\section{PRESERVATION EFFORTS IN SOUTHERN UTAH}

America's newest national monument, Grand Staircase-Escalante (Escalante) covers over 1.7 million acres. (See Figure 5.) On its borders are Bryce Canyon National Park, Capital Reef National Park, Glen Canyon National Recreation Area (which is adjacent to Canyonlands National Park), the Paria Canyon Wilderness, the Death Hollow Wilderness, and Dixie National Forest. With the creation of Escalante, President Bill Clinton created the largest national monument in the lower forty-eight, and the largest federally protected area in the continental United States: over 3.5 million acres of contiguous preserved land (Richard 1996).

Escalante, Clinton claimed, was created to protect the region from mineral exploration and exploitation (Clinton, 1997a). Escalante includes the Kaiparowits Plateau; the prospective site of a large coal mine. The Kaiparowits Plateau and other areas within the monument are rich in mineral resources, such as coal, oil and tar sands, and non-fuel resources such as alabaster, gold, titanium, and uranium. ${ }^{4}$

The struggle to prevent mineral development in southern Utah began in the 1930's when plans for a 4.4 million-acre Escalante National Monument became the pet project of Harold Ickes, Franklin Roosevelt's Secretary of Interior (Richardson 1973). Ickes, always the great orchestrater of conservation projects, borrowed the concept from Harry A. Aurand, a Denver geologist. Aurand contacted the National 


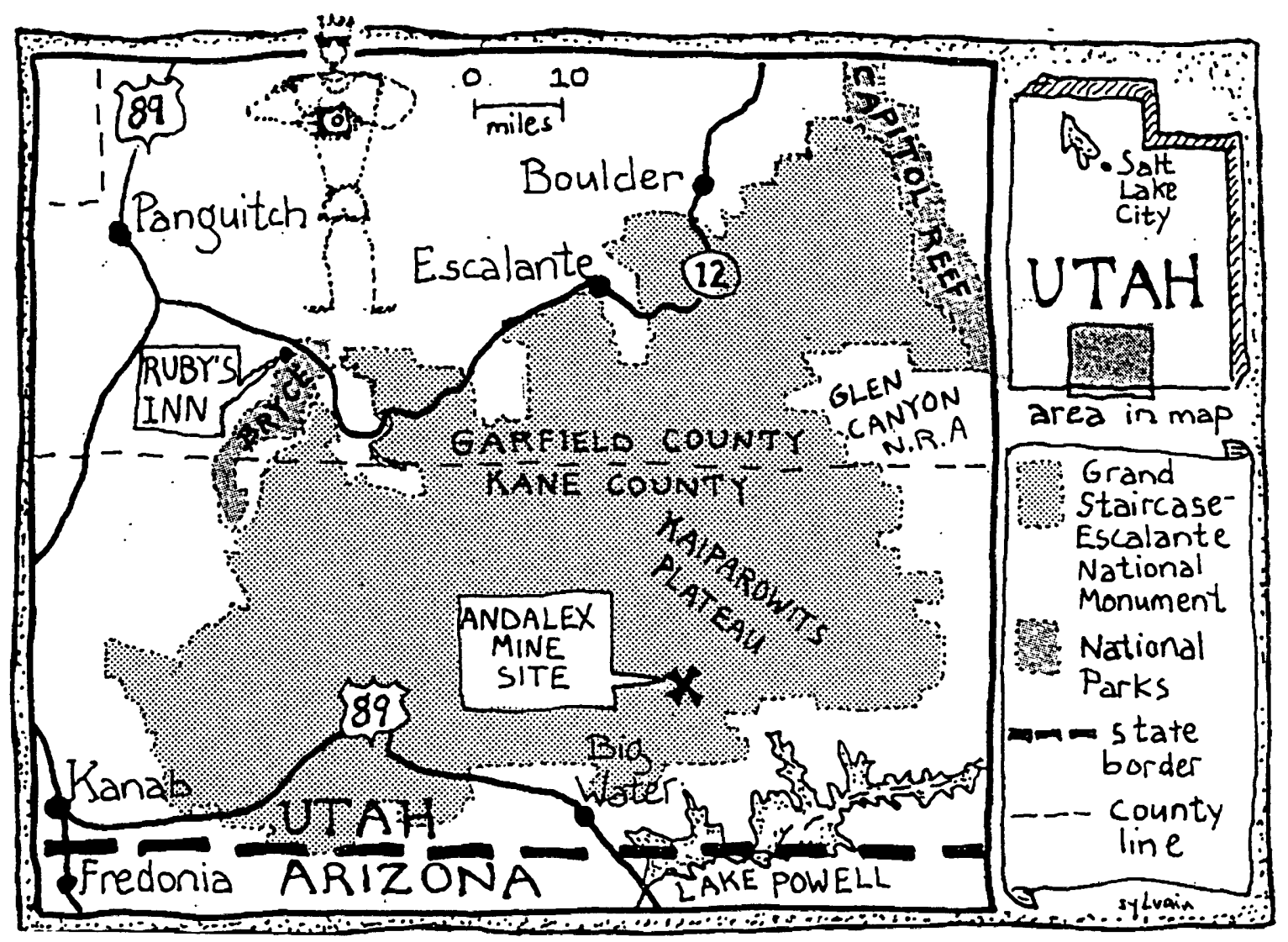

Figure 5. Map of the Grand Staircase-Escalante National Monument. (Source: Larmer 1997) 
Park Service in 1934 urging them to consider portions of southern Utah for national park status. One year later, the Utah Senate identified a national park as a potential project to create Depression-Era jobs. The project proposal evolved into a 570squaure mile national park, and was met with approval by the public.

Enter: Ickes. When Ickes read reports describing the area he also envisioned Depression relief and embraced the project. With Ickes' backing the National Park Service developed a plan to create Escalante National Monument. Icke's plan, however, stunned Utahns with its recommendation for a 6,969-square mile park. The size of the park raised questions within the Park Service and the state of Utah. The Utah Governor, Henry Blood and Utah Senator William King voiced strong opposition to Ickes' plan (Richardson 1973). The proposal was revised and a 2,450square mile park was proposed in 1937. By then park opponents who were concerned about mining and grazing rights were gaining momentum. Growing concern about the war in Europe also played a role. As the importance of the hydroelectric potential of the Colorado River grew it brought more park opponents to the battle. Ickes struggled with the state of Utah and congress until 1941 when the United States entered World War II. The entry of the United States into the war bolstered the cause of hydroelectric development in the area. In 1942 Ickes admitted defeat and dropped all efforts to create a new monument in the region. (Smith 1996).

More recently, the effort to protect the region has been fought by wilderness advocates who organized and drafted a congressional bill. The America's Red Rocks Wilderness Bill (H.R. 1500/S. 733) was first introduced in 1986 by Utah citizens. 
Reintroduced in 1995 by a congressman from Utah, Wayne Owens, the bill proposes to protect 5.7 million acres of land in southern Utah, including land in what is now Grand Staircase-Escalante National Monument. Over 400,000 acres of the proposed wilderness is in the Grand Staircase-Escalante region, including 145,800 acres on the Kaiparowits Plateau. This act now has the support of the Utah Wilderness Alliance, the Southern Utah Wilderness Coalition, the Sierra Club, the National Parks and Conservation Association, as well as eleven members of the Senate, and 139 members of the U.S. House of Representatives (SUWA 1998c). The bill is currently under consideration by the $105^{\text {th }}$ Congress.

\section{THE EXECUTIVE BRANCH TAKES AN INTEREST}

In 1995 the Clinton administration became actively involved in efforts to preserve Southern Utah wilderness. Plans to create a new national monument were under consideration as early as July 1995. The administration made a decision to proceed with the formation of the monument by August 1995 (McGinty 1997e). However, the plans were kept secret. The administration's interest in Escalante was not made public until a few days before the proclamation creating Grand StaircaseEscalante National Monument. The announcement establishing Escalante was originally scheduled for August 1996, but for unknown reasons it was delayed. The creation of Escalante included several controversial elements including: doubts that the President initiated the planning process, the secrecy and denial of plans to establish it, and the motives for establishing the new monument. Details of the creation of 
Escalante, and the extent of the secrecy involved in its planning, were not made public until memorandums related to the planning of the monument were released in November 1997. These memos were subpoenaed by congress, and are now a part of the Congressional Record.

According to memos generated by the Council on Environmental Quality and recorded in the Congressional Record, the intention of the administration in preserving Utah lands was to protect the land adjacent to Arches National Park and Canyonlands National Park from pending anti-wilderness congressional action (McGinty 1997b). The Antiquities Act was considered an appropriate tool for accomplishing that task. By the end of March 1996 the crusade to create a national monument was in motion, but with the added potential for political gain.

The wilderness protection benefits of a new national monument was viewed as instrumental in acquiring more votes in the impending November 1996 Presidential Election. The creation of a national monument was expected to increase voter support in Arizona, California, Colorado, Nevada, Oregon, and Washington (McGinty 1997e). The staff was not concerned about losing Utah votes. The state is fiercely Republican and in the 1992 election Clinton was third in votes behind Ross Perot (Egan 1996). In an August 14, 1996, memo to the President, McGinty outlines the political benefits for Clinton. Just a few months away from the November election, she highlights the potential votes resulting from the monument proclamation stating, "designation of the new monument would create a compelling reason for persons who are now disaffected to come around and enthusiastically support the Administration" (McGinty 1997d). 
As a side note: Clinton was reelected in 1996, but received only thirty-three percent of the Utah votes. In Garfield County he managed only thirteen percent and in Kane County he lost to Robert Dole, the Republican candidate, by fifty-seven percentage points (Cates 1997a).

As plans for the proclamation moved forward the staff focused on compliance of environmental laws, such as the National Environmental Policy Act (NEPA). One Council on Environmental Quality memo to President Clinton indicates the concern to document the President's initiative in creating Escalante, therefore eliminating the need to follow environmental regulations in establishing the park. The memo states,

We have prepared for your signature the attached letter to Secretary of the Interior Bruce Babbit. The letter will serve as a critical piece of the administration record if, as we discussed, you decide to designate certain lands in southern Utah as national monuments under the Antiquities Act of 1906.

Ordinarily, if the Secretary were on his own initiative to send you a recommendation for the establishment of a monument, he would most likely be required to comply with NEPA and certain federal land management laws in advance of submitting his recommendation. But, because he is responding to your request for information, he is not required to analyze the information or recommendations under NEPA or the other laws. And, because Presidential actions are not subject to NEPA, you are empowered to establish monuments under the Antiquities Act without NEPA review.

The text of the letter is modeled after a letter sent by President Carter to the Interior Department seeking information on lands in Alaska suitable for monument designation... The legality of the President's actions was challenged by monument opponents, but was upheld in federal courts. The letter to Interior was specifically cited by the courts as a principal basis of their finding of legality. We recommend that you sign the letter (McGinty 1997f).

Opponents of Escalante interpreted the efforts to obtain Clinton's signature on this letter as an indication that the new monument was the brainchild of Clinton's 
staff, not of the president himself (Hansen 1997). If this was the case, the planning of the monument should have been in compliance with NEPA. ${ }^{5}$ The omission of NEPA regulations and McGinty's involvement is just one aspect of the monument's establishment that was criticized by opponents. A March 25, 1996, e-mail from McGinty to other White House staff members is also criticized. It states, "We do not really know how the enviros (sic) will react and I do think there is a danger of 'abuse' of the withdraw/antiquities authorities especially because these lands are not really endangered" (McGinty 1997c).

As plans for the monument neared completion, the White House staff members working on the proposal became concerned that information about their intentions would leak and give congress time to react and curb the monument plans. Their fears became reality the first week of September when both the Washington Post and the Los Angeles Times published stories suggesting plans for the creation of a new monument in southern Utah. Utah politicians were stunned and concerned. Inquiries made of White House staff members, and the Interior Secretary Bruce Babbitt, by Utah Governor Mike Leavitt were met with denial of any decision to create a new monument (Cates 1997b). Utah Senator Orrin Hatch claims that Babbitt and Council on Environmental Quality Director, Kathleen McGinty told him and Senator Bob Bennett of Utah that the rumors about the new monument were false, "and that no such action was contemplated" (Hatch 1997).

The decision to create Escalante was kept secret from Leavitt until the day the proclamation was signed. Though the governor was in favor of preserving portions of 
the new monument he felt the omission of public and state involvement in the monument planning process was a mistake (Cates 1997b). Fearing that the proclamation would cause protest in Utah, neither the signing ceremony nor the announcement of the new monument was made in Utah. Instead, Clinton chose the rim of the Grand Canyon for the ceremony. The Grand Canyon provided both a dramatic backdrop for his proclamation and a safe distance from angry Utahns. ${ }^{6}$

When news of Clinton's plans to establish Escalante reached Governor Leavitt, he flew to Washington D. C. He was able to discuss his concerns and the concerns of the State of Utah with the President in a September phone conversation (Cates 1997). Leavitt was angered by the secrecy surrounding the creation of Escalante, and concerned that Utah politicians would be usurped by a presidential proclamation.

\section{PROMISES OF THE PRESIDENT}

Leavitt's discussion with the president was not completely fruitless. In his speech announcing Escalante, Clinton made clear that the proclamation applied only to federal lands and that the federal government made no claims on water rights. $\mathrm{He}$ stated that "families will be able to use this canyon as they always have - the land will remain open for multiple uses including hunting, fishing, hiking, camping, and grazing" (Clinton 1997a). He also promised the state of Utah that he would use the power of his office to expedite exchanges for the Utah State Institutional Land Trust (School Trust) in-holdings within the monument, and other in-holdings on federally reserved land. In reference to the School Trust lands he assures Utahns that, "creating 
this national monument should not and will not come at the expense of Utah's school children" (Clinton 1997a).

Although Clinton's speech made a marginal effort to placate Utah, it also made it clear that coal development was not welcome in the monument. Pleased with PacifiCorp's agreement to trade its coal mine leases Clinton urged that "Andalex, a foreign company, will follow PacifiCorp example and work with us to find a way to pursue its mining operation elsewhere" (Clinton 1997a). Clinton emphasized the curtailment of coal mining on the threatened lands when stating “ ... we can't have mines everywhere, and we shouldn't have mines that threaten our national treasures" (Clinton 1997a). He compared the threats to the canyons of the Escalante and Kaiparowits Plateau to development threats that faced the Grand Canyon before it enjoyed national monument status. He claimed it was his "obligation to preserve our natural heritage" just as Teddy Roosevelt preserved the Grand Canyon in 1903. Progress, says Clinton, is sometimes measured by protecting frontiers rather than mastering them (Clinton 1997a).

The frontiers that Clinton protected through executive order are outlined in his proclamation authored by noted University of Colorado law professor, Charles Wilkenson (Hansen 1997). Like many of the preceding monument proclamations it is careful to indicate that the area included in the monument is "confined to the smallest area compatible." The proclamation's characterization of the monument as, uniquely remote and vast can be interpreted as an attempt to relate the large size of the monument as part of its scientific value. Besides open space the unique pre-historic, 
historic, biologic, and scientific features of the area are also described. The document also assigns the management of the monument to the Bureau of Land Management. The Bureau of Land Management was allowed three years to devise and submit a management plan to the Secretary of Interior. This is the first national monument or park for which the Bureau of Land Management is responsible.

\section{THE RESPONSE}

The announcement of the new monument made news across the nation.

Environmental groups were ecstatic (Mapes 1996). In a statement made just before Clinton's announcement, Charles Wilkinson praised the president for the giving the country the "lasting gift of another national monument, " and continued, saying that only "through presidential courage and wisdom and spirit" are we fortunate enough to have the Grand Staircase-Escalante National Monument (Wilkinson 1996, 11). Some Utahns supported the proclamation but believed that "they've been stepped on because they weren't consulted about it" (local business-owner Charlie Neumann quoted in Cates 1997b). Ross C. Anderson, a Democratic candidate for congress, claimed that he believed most Utahns to be in favor of the monument designation (Brooke 1996).

A September poll in Deseret News showed that Anderson might not be in tune with his constituents. The poll claimed that only twenty-nine percent of Utahns were in favor of the monument, forty-nine percent opposed the monument, and sixty-one percent said they were against the process used to create the monument (Larmer 1996). By October the number in favor had risen slightly to thirty-seven percent 
(Richard 1996). One year after the proclamation much of the anti-monument sentiments had faded. Few local opponents bother to attend Bureau of Land Management planning meetings where environmentalists now constitute the largest interest group (Israelsen 1997a).

Immediately following the proclamation residents of Kane and Garfield Counties (the counties where the monument is located) spoke out against the president's action. As in the case of previous proclamations, concerns about loss of jobs, changes in the way of life, outside interference, and state's rights were voiced. The details of the planning process were not known at that time. The counties' depressed economy fueled fears about job losses. Kane and Garfield Counties are largely rural and sparsely inhabited. In 1996, the population of Kane County was 10,000 and the population of Garfield County was only 4000 . Most of the land is in state or federally owned. In Kane County the government owns ninety-five percent of the land (Brooke 1996). Approximately ninety-eight percent of Garfield County land is federally owned (Larder 1997).

It is not clear if Andalex would have ceased operations on the Kaiparowits Plateau without the establishment of the monument (Woolf 1997). In the minds of the residents the monument is at fault. The mine would have given the local economy a boost, provided jobs ${ }^{7}$, and paid $\$ 160$ million royalties for the state. The estimated loss to the School Trust was between $\$ 1.4$ billion and $\$ 2$ billion dollars (Allison 1997). The School Trust had 337 parcels covering 175,000 acres in Escalante (Israelsen 1997a). 
The economies of both counties rely primarily on cattle, lumber, and tourism (Powell 1996). Area tourism has increased since Grand Staircase-Escalante National Monument was established. By April of 1997, visitor counts at Bureau of Land Management offices in the area had nearly doubled from the previous year (Associated Press 1997). Though some residents were optimistic about the increased tourism and the jobs it brings, many were concerned about the low-paying, seasonal nature of the tourist industry. Others were concerned that increased visitation will stress an already outdated county infrastructure. The influx of outsiders was also viewed as a threat to the rural lifestyle that the residents of Kane and Garfield Counties cherish.

The interference of the government in the management of the land was resented. Residents claimed that the most qualified managers are those who knew the land best, and rely on it for their livelihood (Cates 1997b). Clinton has kept his promise to allow grazing to continue, but the Bureau of Land Management is paying more attention to grazing practices. About 7,000 cattle graze within the monument boundaries. The locals, however, claim that the environmentalists have done more harm than their cattle by bringing attention to the area (Associated Press 1997; Larmer 1997). 


\section{TAKING ACTION: PROTEST, LAWSUITS AND LEGISLATION IN RESPONSE TO GRAND STAIRCASE-ESCALANTE NATIONAL MONUMENT}

The most vocal citizen protests emanated from the towns near the new monument. In protest, citizens of Kanab released black balloons. Both Clinton and Babbitt were hung in effigy in the town of Escalante (Brooke 1996). Kane County Commissioner Joe Judd announced that the county would no longer cooperate with the federal government on other issues (Larmer 1996). But the boldest protest was that initiated by Kane and Garfield County Commissioners. Following the example of other Utah counties protesting H.R. 1500, and claiming that they had the right of way to construct highways over public lands, the commissioners sent bulldozers into the monument cutting illegal roads across the protected lands, (SUWA 1996b).

Department of the Interior Secretary Bruce Babbitt responded by filing suit against the counties.

Babbitt was not the only party filing lawsuits. Two lawsuits were brought against the federal government: one by the School Trust and one by the Utah Association of Counties. The Utah Association of Counties filed suit in June 1997. It claimed that by failing to hold public meetings and produce environmental studies the monument was in violation of the Wilderness Act, NEPA, and the Federal Land Policy Management Act (FLPMA). The Utah Association of Counties also accused Clinton of exceeding the "smallest possible area" tenet of the Antiquities Act. They also alleged that the monument was created to advance Clinton's political career, not to protect the land. The Utah State Legislature backed both the School Trust and the Utah 
Association of Counties and in early 1998 voted to give $\$ 75,000$ to support the lawsuits (SUWA 1998b).

The School Trust lawsuit filed in June 1997 sought compensation for lost revenue. The School Trust asserted that the promise made by Clinton to expedite the exchange of school-trust lands had not been kept. However, on May 8, 1998, Governor Mike Leavitt and Interior Secretary Bruce Babbitt "signed a peace treaty of sorts to end the...War over school trust lands locked in federal reserves" (Israelsen 1998,1). The New York Times called it the "largest land swap in the history of the continental Unites States" (Associated Press 1998). The agreement requires Utah to give up 376,739 acres of school trust land, including 176,699 acres in the Grand Staircase-Escalante National Monument. The School Trust will receive fifty million dollars in addition to mineral rights and developable lands in other parts of Utah (Spangler 1998) ${ }^{8}$ An act of congress is required to finalize the agreement. By May 9 , Rep. Jim Hansen had already made public his plans to introduce a bill in the House by the second week of May (Israelson 1998). The School Trust promised to drop its lawsuit if the bill is approved in congress.

Monument opponents also put the legislative branch to work. Clinton's proclamation inspired a flood of legislation aimed at changing the Antiquities Act (see Table VI). These bills sought limits to the extent of the president's power, either by reducing the number of acres that can be included in a national monument or by requiring congressional approval. In some cases the proposed limits would apply only in specific states such as Idaho, California, or Oregon. Most of the bills either died in 
TABLE VI

BILLS IN CONGRESS RELATED TO THE GRAND STAIRCASE-ESCALANTE NATIONAL MONUMENT AND THE ANTIQUITIES ACT OF 1906

\begin{tabular}{|c|c|c|c|}
\hline Session & Bill & Date & Brief Description \\
\hline 104th & S.2092 & $9 / 19 / 96$ & Prohibits NM in ID w/o Act of Congress \\
\hline 104th & S. 2150 & $9 / 1 / 96$ & Prohibits NM w/o compliance of EPA, ESA etc \\
\hline 104th & H.R. 4118 & $9 / 19 / 96$ & Limits Pres. authority to declare NM over 5000 acres \\
\hline 104th & H.R. 4120 & $9 / 19 / 96$ & Prohibits NM in ID w/o Act of Congress \\
\hline 104 th & H.R. 4147 & $9 / 27 / 96$ & NM extension prohibited w/o Congress approval \\
\hline 104th & H. R. 4214 & $9 / 26 / 96$ & NM proclamations must have Congressional approval \\
\hline 104th & H. R. 4242 & $9 / 27 / 96$ & Can not establish NM in CA w/o Congress \\
\hline 104th & H.R. 4294 & $9 / 28 / 96$ & Prohibits NM in OR w/o Act of Congress \\
\hline 105th & S. 62 & $1 / 21 / 97$ & Prohibits NM in ID w/o Act of Congress and public participation \\
\hline 105th & S. 357 & $2 / 25 / 97$ & Authorizes BLM to manage GSENM \\
\hline 105th & S. 477 & $3 / 19 / 97$ & $\begin{array}{l}\text { Governor, State Legislature \&Act of Congress to establish NM } \\
\text { over } 5000 \text { acres }\end{array}$ \\
\hline 105th & H. R. 596 & $2 / 5 / 97$ & Prohibits establish Of NM w/o Act of Congress \\
\hline 105th & H. R. 597 & $2 / 5 / 97$ & $\begin{array}{l}\text { Prohibits NM in ID w/o Act of Congress and public participation } \\
\text { Governor, State Legislature \&Act of Congress to establish NM } \\
\text { over } 5000 \text { acres }\end{array}$ \\
\hline
\end{tabular}


committee or on the floor, but one bill sponsored by Utah Representative Jim Hansen, H.R. 1127, is still pending. H. R. 1127, also known as the National Monument Fairness Act of 1997, was first introduced in the House March 19, 1997. Utah Senators Orrin Hatch and Bob Bennett sponsored a similar bill, S. 477, in the Senate. The National Monument Fairness Act proposes that amending the Antiquities Act "...to require an Act of Congress and the consultation with the Governor and state legislature prior to the establishment by the President of national monuments in excess of 5,000 acres" (H.R. 1127 1997). The bill requires that the President and Secretary of Interior submit their national monument proposal to congress before issuing a proclamation. It allows the governor ninety days to respond to the proposal and requires that it be submitted to congress within 180 days.

The bill was approved by the House Committee on Energy and Natural Resources, and referred to the floor for a vote in October 1997. After being amended to require monuments of over 50,000 acres to require consultation and congressional approval, the bill passed in the House: the vote was 229 yeas and 197 nays (see Table VII). The partisan influence of its success is evident. Only 27 Democrats voted for the bill, and only 23 Republicans voted against the bill. Republican support outnumbered Democratic opposition 202 to 173 . The bill is now awaiting Senate approval. If it does pass in the Senate, it is likely to be vetoed by the president. Another bill of interest is S. 357, The Grand Staircase-Escalante Resource Act. The official title of this bill states, that it is a bill to authorize the Bureau of Land Management's supervision of the monument, but the bill's sponsor, Senator Bob 
TABLE VII

RESULTS OF ROLL CALL-VOTE NUMBER 495 ON THE NATIONAL MONUMENT FAIRNESS ACT OF $1997 \mathbb{I N}$ THE HOUSE OF REPRESENTATIVES, $105^{\mathrm{TH}}$ CONGRESS

\begin{tabular}{|r|c|c|c|}
\hline & YEAS & NAYS & NO VOTE \\
\hline Republicans & 202 & 23 & 1 \\
\hline Democrats & 27 & 173 & 6 \\
\hdashline Independents & & 1 & \\
\hdashline Total & 229 & 197 & 7 \\
\hline & & & \\
\hline
\end{tabular}


Bennett, has other motives (S. 357 1997). In a press release issued from Bennett's office he claims that the purpose of the bill is to "preserve, in law, the president's 'monumental' promises" (Bennett 1997, 1). Six western Republican Senators cosponsored S. 357. It was referred to the Senate Committee on Energy and Natural Resources on February 25, 1997, and then to the Subcommittee on Parks, Preservation and Recreation. After subcommittee hearings in May, the bill was referred to the Department of the Interior and the Office of Management and Budget on May 23, 1997. The bill, if passed, would authorize appropriations for the monument and require that the Secretary of the Interior:

1. manage the monument using multiple use, sustained yield principles that provide ecological and economic sustainability,

2. protects and interprets the resources of Escalante,

3. "manage such resources in a way that provides for economic sustainability of local communities," and

4. "delegate authority to manage the Monument to the Director of the Bureau of Land Management" (S. 357 1997),

5. requires the Department of the Interior to expedite the School Trust land exchanges, and do a valuation on the trust lands and to submit that analysis to congress,

6. establish a Escalante Advisory Committee that will oversee the development, management of resources and the exchange or disposal of trust lands; the members of this committee are to be appointed by the Governor of Utah. 
In a distantly related House Resolution (H. Con. Res. 183) another controversial aspect of the Escalante proclamation was revealed. Introduced October 31, 1997, by Arizona Representative Matt Salmon (R), H. Con. Res. 183 seeks an independent council to investigate the 1996 Clinton-Gore presidential campaign. The resolution alleges that funds donated by various foreigners were accepted and used for campaigning by Clinton. This is a violation of campaign laws. Some of the foreigners that the president allegedly accepted funds from are members of the Lippo Group, which controls a low-sulfur coal deposit in Indonesia. The resolution reads:

The President's decision to designate 1,700,000 acres of Utah wilderness as a national monument, which halted plans to mine the world's largest deposit of clean burning super compliance coal when the second largest deposit of this type of coal lies in Indonesia, raising concerns that the Lippo group influenced the President's decision $(\mathrm{H}$. Con. Res. 183 1997).

The resolution was referred to the House Committee on the Judiciary.

\section{TOO SOON TO KNOW}

Similar to Jackson Hole National Monument and the monuments on the Alaska d-2 lands, the establishment of Escalante resulted in public response that was manifested in protest, legislation, and lawsuits. As in the case of those monuments, economics, states' rights, and constitutionality of the proclamation were questioned. Another wrinkle is the legality of the proclamation, questioned by opponents and based on the motives for creating the monument. It is to soon to know if the Antiquities Act will withstand the challenges presented by the Utah Association of Counties lawsuit, House Resolution 183, and H. R. 1127. The influence of the Bureau 
of Land Management is also a wildcard. The Bureau's management philosophy must meet congressional approval. Although the precedent for allowing grazing in national monuments was established by Jackson Hole National Monument, no national monument has had active mineral leases, or allowed mineral exploration. 


\section{CONCLUSION}

The Antiquities Act has weathered more than ninety years of debate. Over the course of those years it has been celebrated and cursed. The presidents using the Act have been glorified and vilified. Whether one is a proponent or opponent, the Act has been unarguably effective in resolving federal land use issues. In cases such as Muir

Woods, Grand Canyon, Mount Olympus, Jackson Hole, the Alaska d-2 lands, and Grand Staircase-Escalante National Monuments, where the best use of federal lands was under debate, the use of the Antiquities Act demonstrated a strong federal commitment to preservation over development. In the face of equally strong opposition from local interests, each of these monuments has endured.

Local opposition is a common theme connecting the case histories discussed in this paper. In eras of differing political climates, economic conditions, and environmental advocacy, the general responses to the use of the Antiquities have been similar. The presidential proclamations creating Jackson Hole, the Alaska d-2 lands, and Grand Staircase-Escalante each usurped a deadlocked congressional battle over the future of federal lands, igniting a backlash of public protest.

In these cases, strong public support for the protection of the lands was evident prior to the presidential proclamation. In Jackson Hole, efforts to protect the area gained enough support to create Grand Teton National Park. The d-2 lands and Grand Staircase-Escalante National Monument also had supporters fighting to preserve the 
areas for future generations. However, post-proclamation dramatics protesting preservation have become the trademark response to presidential intervention. In some cases the opponents support preservation but condemn the use of presidential power. The reasons given for protesting are many, and include actions and statements that characterize the use of the Antiquities Act as (1) threatening to individual rights, (2) eliminating public participation, (3) brandishing too much government power, (4) excessive use of presidential power, (5) violating the tenets of the Antiquities Act, (6) violating state's rights, (7) threatening a way of life, and (8) threatening the local economy. Concern for those issues has resulted in demonstrations, lawsuits, and congressional bills attacking the Act and the monuments it created.

Despite significant legal and legislative challenges, the Antiquities Act and most of the monuments established through its use remain. The negative public response to the Act and the monuments has not been able to dissuade presidents from using executive authority. Muir Woods National Monument was established in defiance of development pressure. The Grand Canyon National Monument survived as a national treasure contrary to development pressure and lawsuits. Mount Olympus National Monument became Olympic National Park even after being faced with heavy pressure from logging interests. Jackson Hole National Monument was incorporated into Grand Teton National Park contrary to lawsuits and legislation that sought abolishment. The seventeen national monuments created in Alaska by President Carter remain under federal protection despite protests, lawsuits, and legislative attempts by Alaskans to reverse Carter's proclamations. The fate of Grand 
Staircase-Escalante National Monument, though too soon to call, has already seen lawsuits dropped, and the legislation proposing protection for the surrounding wilderness (H.R. 1500) continues to gain support in congress.

Jackson Hole and the Alaska d-2 lands are similar to Grand Staircase-Escalante in the amount of anger sparked by their proclamations. Citizens protested by staging demonstrations and waging verbal warfare on Washington, DC. Jackson Hole protestors drove cattle across the new monument, $d-2$ opponents built bonfires on monument land, and in Southern Utah bulldozers plowed roads in protest of Grand Staircase-Escalante. Each of these acts was organized in defiance of the federal government's control of its own lands.

Civil protest was followed by lawsuits (one exception was Muir Woods where the lawsuit preceded and was the catalyst for the presidential intervention). In response to the creation of Grand Canyon and Mount Olympus National Monuments, lawsuits were filed by developers with an interest in profiting from the resources. The Wyoming government sued the federal government, attacking the president's authority to use the Antiquities Act on Wyoming lands. The dismissal of that case in federal court established a precedent. Carter's Alaskan monuments ignored a lawsuit that was filed prior to his proclamations. The suit sought an injunction on the use of the Antiquities Act in Alaska. In addition the monuments survived the assault of twentyseven lawsuits which were filed after the proclamations. Grand Staircase-Escalante has been the target of several suits. One of the suits with strong financial and public support was resolved a year and a half after the establishment of the monument, when 
Utah and the federal government agreed on a land swap to resolve a long-standing dispute over state inholdings on federal land.

The war against the Antiquities Act and the monuments it has created was also waged in congress. Bills were proposed in the House and Senate in response to Jackson Hole National Monument, the d-2 land monuments, and Grand StaircaseEscalante National Monument. Legislation that would abolish Jackson Hole National Monument passed in both the House and Senate, but was vetoed by the president. This was the first time congress had voted to reverse a national monument proclamation, and the first time a president had vetoed a congressional act seeking to abolish a monument. For the $\mathrm{d}-2$ lands in Alaska, bills tendered in response to the president's action received little notice, as congress worked to agree on the legislation which prompted the use of the Act. It is too soon to predict the final outcome of the legislative battle over Grand Staircase-Escalante. House bill, H. R. 1127, which proposes limitations to the Antiquities Act passed, however, H. R. 1500, which seeks to grant wilderness status to areas within and surrounding the monument, continues to gain support (SUWA 1998c).

The impact of the demonstrations, lawsuits, and legislation on the Antiquities Act and the monuments created through its has been minimal. For the Alaska lands, the negative public response had little impact. Only two years after President Carter signed the proclamations, congress reached an agreement on how to manage the lands. Six of the Alaska monuments have become national parks. However, for Jackson Hole the public response did effect change. Eight years passed before the new 
monument obtained congressional approval and funding. In addition, for the first time the Antiquities Act was amended, essentially prohibiting its use in Wyoming. President Clinton's proclamation mandated the completion of a management plan for Escalante by 1999 , but a complete management plan does not necessarily guarantee funding for the monument. On the other hand, the land-exchange agreement between Utah and the federal government will make it more difficult for Escalante opponents to abolish the monument in the future.

Opponents of the Antiquities Act have been unsuccessful for a many reasons. One of the primary sources of opposition is the fear for economic well being. Though a common chord in protest of the Act, in many cases these fears proved unfounded. For example, contrary to the predictions of nervous landowners, Jackson Hole land values increased after the creation of Jackson Hole National Monument. Another reason is that the passage of time not only dulls the anger of opponents, but also allows proponents more time to rally support. This has been the case with Muir Woods, Grand Canyon, Mount Olympus, Jackson Hole and Grand StaircaseEscalante. In many cases the negative response was local or regional, and support from other areas of the country outweighed the opposition. Finally, the ambiguity of the Antiquities Act makes the law flexible, allowing the president to adjust the details of management and impact through careful wording of the proclamation.

In each of the controversial cases discussed in this paper, the scope of the Antiquities Act was expanded in terms of the values being protected, monument size, or land use. The public had little influence in reversing that expansion. The 
Antiquities Act was designed as a tool to provide protection to threatened lands. It has protected federal lands and in many cases the national interest. The historic and scientific values of once controversial monuments such as the Grand Canyon, Muir Woods, Mount Olympus, Jackson Hole, and the d-2 lands, are now indisputable. These monuments have evolved to represent part of our natural national heritage. Only time will tell if the same can be said for Grand Staircase-Escalante National Monument. 


\section{ENDNOTES}

${ }^{1}$ Forests were not the only front for conservation advocates. Presidents and congress used their authority to protect lands with scenic and recreation value. The creation of the country's first national park, Yellowstone, was in 1872. It was followed by Yosemite and Sequoia National Parks in 1890. National Park status removed thousands of acres from potential harms.

${ }^{2}$ A geographical definition of human territoriality outlined by Robert Sack states that territoriality is "a spatial strategy to affect, influence, or control resources" (Sack $1986,1)$. He claims there are three phases to developing territorial attachment. The first is classification of the territory either by type or area. The second is to communicate the boundaries of the area. This communication can take any form: written contracts, fences, and signposts or evens gestures. The third phase is to enforce the boundaries thus making it clear who has the right to use the territory (Sack 1986).

${ }^{3}$ Responding to Roosevelt's aggressive implementation of the Forest Reserve Act, congress took direct action in 1907 to reduce the use of executive order by passing the Fulton Act prohibiting the president from withdrawing forest land in Colorado, Idaho, Montana, Oregon, Washington, and Wyoming. The passage of the Fulton Act failed to stop withdrawals by Roosevelt. Furthermore, the presidents to succeed Roosevelt used their executive privilege at roughly the same rate (King and Ragsdale 1988).

${ }^{4}$ Exploration of the fuel resources began as early as late 1800's in some small coal mines near the present-day town of Escalante. Though little new exploration had occurred for several decades these mines continued to produce coal until 1960. During the 1960s twenty-three different coal mining companies obtained leases and drilled over 1000 test holes in the area. By 1965 plans to develop a coal burning plant were being pursued by Southern California Edison Power Company. Utahns anticipated economic growth and decreased unemployment. However, the difficulties presented by environmental groups, federal agencies, environmental regulations, and construction costs proved the project impractical. The efforts to develop the plant were abandoned in 1975 (Powell 1996).

In the late 1980s Andalex Resources obtained leases on the Kaiparowits coalfield. The company continued to research the viability of mining in the area until shortly after Clinton's proclamation. The Kaiparowits Plateau coalfield is vast and valuable. An estimated 11.36 billion short tons of recoverable coal are present in the field. What makes the coal in the area even more valuable is its low sulfur content. It is estimated that the sulfur content of the coal in Kaiparowits averages less than one 
percent (Allison 1997). Low sulfur coal is preferred for meeting the market demand for lower pollution emissions. However, the remoteness of the area makes the recovery of the coal very expensive. It is questionable whether Andalex would have initiated mining in the area, even without the establishment of Escalante, because of the excessive transportation costs involved (Turner 1997).

Another coal mining interest, PacifiCorp, had 18,000 acres of coal-lease land in the area. It never pursued development of those leases. In fact, it had negotiated a trade with the federal government for leases on other lands in Utah prior to the designation of the area as a monument. PacifiCorp claims that it was not involved in the planning of the monument and was surprised by the September 18, 1996, announcement (Oregonian 1996).

Coal is not the only fuel resource of the region. Oil exploration began in 1921 in the NE section of the monument, near Capital Reef National Park. Although over 47 wells have been drilled within the monument boundary since then, only a few of those wells were commercially viable, most were plugged or abandoned. The wells that produced oil and still pump today are located in the Upper Valley Field near Escalante. The field has over 21 active wells, only 5 of which are located on 2000 acres of Escalante. Although the wells produce an average of 20,000 barreis a day, they have already exceeded their estimated capacity and it is uncertain how long they will be commercially viable.

Most recently Conoco, Inc. did some exploratory drilling in Escalante. Conoco filed for the lease in January 1997, and the State of Utah approved the leases in March 1997 (after the monument's establishment). Initially the leases sought by Conoco were on inholdings on the Kaiparowits Plateau. The State of Utah held these lands in trust and the federal government, despite the President's proclamation, did not have jurisdiction on these lands. As of May 1998, the federal government now controls those inholdings. Conoco had also filed for leases on federal lands that were approved in September 1997 by the Bureau of Land Management. Conoco holds over 140,000 acres of leases on state and federal land (SUWA 1996a). By June 1997 Conoco commenced drilling on the state lands. December 1997 brought announcements that Conoco had plugged the well on the Kairopowits and had decided they would not drill again on the site (Gehrke 1997). The federal leases were due to expire on February 8, 1997, (Deseret News 1997) but despite unsuccessful wells on the state land Conoco renewed one of its leases within the monument ( SUWA 1998a). Conoco may drill again on state land in the Smokey Hollow area; an announcement of their plans was expected in March 1998. (SUWA 1998a). At this time the only commercial mineral development in the national monument is in the Upper Valley Field.

${ }^{5}$ The Council on Environmental Quality was created to oversee NEPA and to ensure compliance by government offices of NEPA regulations. 
${ }^{6}$ Efforts at wilderness preservation in Southern Utah provided ample evidence of pubic support. However, Utahns, including Senator Orin Hatch (R), Representative Jim Hansen (R), and Governor Mike Leavitt (R), and Kane and Garfield County citizens objected to presidential intervention claiming they were omitted from the monument planning process.

${ }^{7}$ In Kane County unemployment is about three times higher than the state average: near 10 percent in 1996 (Isrealsen 1997b). The closing of a lumber mill in 1990 caused a drop in average income from $\$ 25,000$ a year in 1990 to $\$ 18,000$ a year in 1997 (Larmer 1997). Many residents were anticipating the boost that mining on the Kaiparowits Plateau would provide the local economies. Conoco's plans to drill for oil and Andalex's plan to mine coal would have provided jobs and income for the small towns near the exploration sites. Proponents of the Andalex mine estimate that it would have created as many as 900 badly needed jobs (Cates 1997b). News of the new monument caused concern that both companies would abandon their projects. Conoco proceeded with their exploration, Andalex, however, decided to withdraw their claims in January 1997.

${ }^{8}$ The May 1988 land swap gives the federal government: 176,669 acres in Grand Staircase-Escalante, 80,000 acres in Utah national parks and recreation areas, 47,480 acres in Indian reservations, 70,000 acres of national forest lands, and 2,560 acres of Alton coal field tracts. In return the State of Utah receives $\$ 50$ million, $\$ 13$ million worth of coal leases in Emery County, 160 million tons of coal, 185 billion cubic feet of natural gas, and 139,000 acres of federal land in other areas of the state (SUWA 1998c). 


\section{REFERENCES}

Albright, H. 1933. Letter to Wilford Neilson, Editor of the Jackson Hole Courier. In Mr. John D. Rockefeller, Jr's. Proposed Gift of Land for the National Park System in Wyoming: History of the Snake River Land Company and Efforts to Preserve the Jackson Hole Country fort the Nation. Bozeman, MT: MSU Library Special Collection.

Allison, M. L. 1997. A Preliminary Assessment of Energy and Mineral Resources within the Grand Staircase-Escalante National Monument, Circular \#93. Salt Lake City, UT: Utah Geological Survey.

Associated Press. 1997. Monument Status May Have Put Escalante in Fatal Spotlight. The Salt Lake Tribune, April 28. 1998. Utah and U.S. Agree to Huge Swap of Land. New York Times, May 10.

Audubon Magazine. 1944. The Director Reports to You: Progress Report on Jackson Hole Controversy. Vol. 46: 244.

Audubon Magazine. 1945. The President Reports to You: Jackson Hole. Vol. 47:54.

Bennett, B. 1997. Holding Clinton to His Word, Bennett Moves to Codify President's Promises on Utah National Monument. Press Release February 24: Salt Lake City.

Berger, R. 1974. Executive Privilege: A Constitutional Myth. Cambridge, MA: Harvard University Press.

Betts, Robert B. 1978. Along the Ramparts of the Tetons: The Sage of Jackson Hole, Wyoming. Boulder, CO: Colorado Associated University Press.

Boyd, Katharine. 1945. Heard About Jackson Hole? Atlantic 175:102-6.

Brooke, J. 1996. A Monumental Debate. Oregonian, October 13: A22.

Calkins, Frank.1973. Jackson Hole. New York: Alfred A. Knopf, Inc. 
Carter, Jimmy. 1979. Designation of National Monuments in Alaska: Statement by the President December 1, 1978. Public Papers of the Presidents of the United States: Jimmy Carter 1978 (2). Washington, DC: US Government Printing Office.

Cates, K. 1997a. How Leavitt Tried to Stop Clinton's Escalante Plan. Deseret News January 16.

1997b. Making of a Monument. Deseret News January 16.

Clawson, M. 1983. The Federal Lands Revisited. Washington, DC: Resources for the Future.

Clinton, W. J. 1997a. Remarks by the President in Making Environmental Announcement. Grand Canyon National Park, Arizona September 18.

Clinton, W. J. 1997b. Establishment of the Grand Staircase-Escalante National Monument: A Proclamation. Executive Order of September 18.

Commonwealth North Federal-State Relations Committee. 1990. In Going Up In Flames: The Promises and Pledges of Alaska Statehood Under Attack, Malcolm B. Roberts Ed. Anchorage, AK: Alaska Pacific University Press.

Congressional Quarterly Almanac Vol. 34. 1978. Carter Acts to Preserve Alaskan Wilderness. Washington DC: Congressional Quarterly, Inc.

Congressional Quarterly Almanac Vol. 35. 1979. Carter Acts to Preserve Alaskan Wilderness. Washington DC: Congressional Quarterly, Inc.

Cooley, R. A.1984. Evolution of Alaska Land Policy. In Alaskan Resources Development Issues of the 1980s, Thomas B Morehouse Ed. Boulder, CO: Westview Press.

Corwin, E.S. 1984. The President: Office and Powers 1781-1984. New York: New York University Press.

Deseret News. 1997. Conoco Opts Not To Drill on Grand Staircase Land: December 24.

Egan, T. 1996. Protection Slated for Southern Utah Canyons. Oregonian, September 17: A09.

Forbes. 1979. Now You See It, Now You Don't, 123(10): 170-3. 
Foresta, R. A. 1984. America's National Parks and Their Keepers. Washington, DC: Resources For the Future, Inc.

Foss, P. O. 1987. Public Lands Policy. Westpost, CT: Greenwood Press.

Gates, P. W. 1968. History of Public Land Law Development. Washington DC: U.S. Government Printing Office.

Gehrke, R. 1997. Conoco is Plugging Well Inside National Monument. The Salt Lake Tribune December 17.

Goetzman, W. H. 1981. Regionalism and Hostility. In That Awesome Space: Human Interaction with the Intermountain Landscape, ed. E. Richard Hart. Salt Lake City, UT: Westwater Press.

Graf, W. L. 1990. Wilderness Preservation and the Sagebrush Rebellions. Savage, MD: Rowman and Littlefield Publishers, Inc.

Hatch, O. 1997. Statement of Sen. Orrin G. Hatch Before The United States House of Representatives Committee on Resources, April 29, 1997. Subcommittee on National Parks, Forests and Lands.

Hirschfield, R. S. 1968. The Power of the Presidency: Concepts and Controversy. New York: Atherton Press, Inc.

Israelsen, B. 1997a. Monument Bomb Slowly Being Diffused. The Salt Lake Tribune, September 3.

1997b. New Ways of Making a Living in Kanab. The Salt Lake Tribune, September 14.

1998. Leavitt, Babbitt Sign Land Swap To Free Up Resources for Schools. The Salt Lake Tribune, May 9:1.

King, G. and Ragsdale, L. 1988. The Elusive Executive. Washington, DC: Congressional Quarterly Press.

Lance, L. 1997. Memo of 3/22/96. Release of House Resource Committee Majority Staff Report on Subpoenaed National Monument Documents. Washington DC: House of Representatives Record for November 7. 
Larmer, P. 1996. A Bold Stroke: Clinton Takes a 1.7 Million-acre Stand in Utah. High Country News 28(18): 8-10.

1997. Beauty and the Beast: The President's new Monuments Forces Southern Utah to Face Its Tourism Future. High Country News 29(7): 1, 8-11.

Lien, C. 1991. Olympic Battleground: The Power Politics of Timber Preservation. San Francisco, CA: Sierra Club Books.

Limerick, P. N. 1987. The Legacy of Conquest: The Unbroken Past of the American West. New York: W. W. Norton and Company.

Mapes, J. 1996. Clinton Urges Demo Congress. Oregonian, Sept. 16:A01.

McBride, Stewart. 1979. The Battle of Alaska: Who Owns the $49^{\text {th }}$ State? Atlantic Monthly 243(5): 80-6.

McGinty, K.A. 1997a. Federal All-in-1 Mail: Utah Letter. Release of House Resource Committee Majority Staff Report on Subpoenaed National Monument Documents. Washington DC: House of Representatives Record for November 7.

1997b.Memo of 3/19/96. Release of House Resource Committee Majority Staff Report on Subpoenaed National Monument Documents. Washington DC: House of Representatives Record for November 7.

1997c. Memo of 3/25/96. Release of House Resource Committee Majority Staff Report on Subpoenaed National Monument Documents. Washington DC: House of Representatives Record for November 7.

1997d. Memo of 8/1/96. Release of House Resource Committee Majority Staff Report on Subpoenaed National Monument Documents. Washington DC: House of Representatives Record for November 7.

1997e. Memo of 8/14/96. Release of House Resource Committee Majority Staff Report on Subpoenaed National Monument Documents. Washington DC: House of Representatives Record for November 7.

1997f. Memo of 7/25/96. Release of House Resource Committee Majority Staff Report on Subpoenaed National Monument Documents. Washington DC: House of Representatives Record for November 7. 
McGreggor, R. .1993. Federal Land, Western Anger: The Sagebrush Rebellion And Environmental Politics. Lawrence, KS: University of Kansas Press.

Miles, J. C. 1995. Guardians of the Parks: A History of the National Parks and Conservation Association. Washington, DC: Taylor and Francis.

Nature Magazine. 1943. As We See It: Jackson Hole-Fact and Fiction. Vol. 36:425.

New York Times. 1943. Bill Bars Funds For Wyoming Park. July 4:12.

New York Times. 1944a. Rebuffs President on Jackson Hole. December 12:18.

New York Times. 1944b. Thomas Dewey on Campaign Trail September 15:2

New York Times. 1944c. Ickes Credits GOP for Jackson Hole. September 16:8

New York Times. 1979a. Letters to the Editor. Jan 1: 16.

New York Times. 1979b. State of Alaska: Full-page ad, July 2:A13.

Oregonian. 1996. PacifiCorp Part of Land Swap: November 7:E08..

Petulla, J.M. 1988. American Environmental History. Columbus, OH: Merrill Publishing.

Powell, A. K (ed). 1996. Kaiparowits. Utah History Encyclopedia. Salt Lake City: University of Utah Press.

Richard, T. 1996. Monument to Outdoors. Oregonian:11/7:E07.

Richardson, E. 1973. Dams, Parks and Politics: Resource Development and Preservation in the Truman-Eisenhower Era. Lexington, KY: The University Press of Kentucky.

Righter, R. W. 1982. Crucible for Conservation: The Creation of Grand Teton National Park. Colorado: Colorado Associated University Press.

Rothman, H. 1989. Preserving Different Pasts: The American National Monuments. Chicago, IL: University of Illinois Press.

Sack, R. D. 1986. Human Territoriality: Its Theory and History. Cambridge: Cambridge University Press. 
Sanborn, M. 1978. The Grand Tetons: The Story of the Men Who Tamed the Western Wilderness. NY: G. P. Putnam's Sons.

Saturday Evening Post. 1943. 221,610-Acre Monument. Vol. 216: 100.

Saylor, D. J. 1970. Jackson Hole, Wyoming: In the Shadow of the Tetons. Norman, OK: University of Oklahoma Press.

Schefielbein, S. 1979. Alaska: The Great Land War. Saturday Review Feb. 17:14-20.

Sellars, R. W. 1997. Preserving Nature in the National Parks: A History. New Haven, CT: Yale University Press.

Smith, C. 1996. Grand Staircase National Monument: It's a New Name- But an Old Idea. The Salt Lake Tribune: October 6.

Spangler, J. 1998. Historic Land Deal With U.S. Hailed As Huge Win For Utah :Babbitt and Leavitt Sign Agreement on School Trust Acres. Deseret News, May 9.

SUWA. 1996a. Monumental Moment for Southern Utah. Southern Utah Wilderness Alliance Newsletter Winter.

1996b. Canyon County Update: Counties Blade Illegal Roads. Southern Utah Wilderness Alliance Newsletter Winter.

1998a. Issues Alert: Conoco. SUWA Alert: A New Year in Canyon Country February 2: 2 .

1998b. Conoco Antes Up, Files Two More Applications For Drilling. SUWA Alert: Utah Wilderness Wins in Court March 10: 2

1998c. New Cosponsors. SUWA Alert: A Land Swap For Canyon Country May 14:1.

Time Magazine. 1943. Wyoming: Gun Play 41(2): 21.

Turner, F. 1997. Oh, Wilderness. Outside Magazine 22 (4): 64-157).

Webb, V. 1933. Conditions set by John D. Rockefeller, Jr. Mr. John D. Rockefeller, Jr's. Proposed Gift of Land for the National Park System in Wyoming: History of the Snake River Land Company and Efforts to Preserve the Jackson Hole Country fort the Nation. Bozeman, MT: MSU Library Special Collection. 
Wilkinson, C. 1996. Clinton Learns the Art of Audacity. High Country New 28 (18): 11.

Woolf, J. 1997. Andalex Gives Up On Kaiparowits Mine. The Salt Lake Tribune, January 24.

Wright, J. B. 1993. Rocky Mountain Divide: Selling and Saving the West. Austin, TX: University of Texas Press.

U.S. Code Congressional and Administrative News $92^{\text {nd }}$ Congress Vol. 2. 1971. St. Paul, MN: West Publishing Co.

U.S. News and World Report. 1978. In Alaska: Biggest Ecology Battle Yet, 84:61. 


\section{APPENDIX}

\section{THE ANTIQUITIES ACT}

The following is the Act of June 18, 1906, 16 U. S. C. $431-433$ commonly known as the Antiquities Act of 1906.

16 U. S. C. 431

National monuments; reservation of land; relinquishment of private claims The President of the United states is authorized, in his discretion, to declare by public proclamation historic landmarks, historic and prehistoric structures, and other objects of historic or scientific interest that are situated upon the lands owned or controlled by the Government of the United States to be national monuments, and may reserve as a part thereof parcels of land, the limits of which in all cases shall be confined to the smallest area compatible with the proper care and management of the objects to be protected. When such objects are situated upon a tract covered by a bona fide unperfected claim or held in private ownership, the tract, or so much thereof as may be necessary for the proper care and management of the object, may be relinquished to the Government, and the Secretary of the Interior is authorized to accept the relinquishment of such tracts in behalf of the Government of the United States.

16 U.S.C. $431 \mathrm{a}$

Limitation on further extension or establishment of national monuments in Wyoming

Limitation on further extension or establishment of national monuments in Wyoming may be under taken except by express authorization of Congress. 